\title{
O ENSINO DA ESCRITA: ANÁLISE DE TRÊS LIVROS DIDÁTICOS DA DÉCADA DE 1940
}

The teaching of writing: an analysis of three textbooks from the 1940s

\author{
Submetido em: 12-09-2012 \\ Publicado em:23-02- 2013 \\ Hydelvídia Cavalcante de Oliveira Corrêa ${ }^{1}$ \\ hydelvidia@bol.com.br \\ Aline Ferreira Lira ${ }^{2}$
}

\begin{abstract}
RESUMO: Este artigo, inserido no campo de atuação da Linguística Aplicada, tem como propósito analisar o ensino da produção escrita no Brasil, na década de 1940, com base em três livros didáticos. Para respaldar a análise e contribuir para o entendimento das práticas de ensino da escrita que caracterizaram esse momento do processo de ensino, foram identificadas as concepções de língua, de sujeito, de professor e de aluno. A partir dos livros estudados, pôde-se confirmar que, nessas obras, a língua é considerada uma representação do pensamento, justificando o modelo de ensino lógico-gramatical.
\end{abstract}

Palavras-chave: Livro Didático. Composição. Redação. Ensino da Escrita.

ABSTRACT: This article, based on three textbooks, belongs to the field of Applied Linguistics, and analyzes the teaching of written production in Brazil, in the 1940s. To support the analysis and to contribute for the understanding of practices of teaching writing which characterized this moment of the teaching process, we identified the concepts of language, subject, teacher and student. From the books studied, we could confirm that, in these books, language is considered as a representation of thought, justifying the logical model of teaching grammar.

Keywords: Textbook. Composition. Writing. Teaching writing.

\footnotetext{
${ }^{1}$ Mestre em Língua Portuguesa pela Pontifícia Universidade Católica do Rio de Janeiro. Doutoranda em Linguística pela Universidade Federal de Santa Catarina. Professora aposentada da Universidade Federal do Estado do Amazonas.

2 Mestre em Ciências Ambientais pela Universidade Federal do Amazonas. Doutoranda em Linguística pela Universidade Federal de Santa Catarina. Professora de Relações Públicas da Universidade Federal do Amazonas. Bolsista da Fundação de Amparo à Pesquisa do Amazonas Fapeam.
}

Work. pap. linguíst., 13(2): 01-36, Florianópolis, jul.set,2012 


\section{Introdução}

O ensino da escrita tem sido abordado sob vários aspectos, quer seja em termos de uma crítica negativa ao papel da escola, quer seja pela apresentação de novas teorias ou concepções diferentes a respeito dos usos da linguagem. Sobre o ensino voltado para os aspectos gramaticais, principalmente para o ensino da gramática normativa ou gramática conceitual, muito facilmente podem ser encontrados compêndios, manuais e livros didáticos que comprovam ter sido o ensino de gramática uma prática bastante dominante nas escolas. No entanto, no que se relaciona ao ensino da redação e composição, termos e conceitos pertencentes a um ensino mais tradicional; ou prática da produção escrita ou produção textual, denominações mais contemporâneas; raras são as fontes que, no Brasil, podem legar um demonstrativo desse processo.

Este trabalho tem como objetivo analisar a prática da escrita apresentada em três livros didáticos da década de 403: Prática de Redação, escrito por Raul Gómez, em 1943; Método de redação, de Carlos Góis, publicado em 1945 e A linguagem usual e a composição, de Júlio Nogueira, datado de 1947, procurando detectar que concepção de língua, de escrita, de sujeito, de professor e de aluno nortearam as atividades de escrita desses livros. Na primeira seção deste artigo, será desenvolvida uma contextualização sócio-histórica da década de 1940, no Brasil, enfatizando, também, as tendências ou características da educação formal. Para uma melhor compreensão do ensino da Língua Portuguesa nos anos 40, no que se refere às práticas pedagógicas da produção escrita e à adoção do livro didático nas escolas, fará parte da segunda seção uma abordagem sobre as concepções de língua e de produção escrita. Uma abordagem sobre as concepções de língua e de produção escrita antecipa a quarta seção voltada para as concepções de sujeito, de professor e de aluno.

Quanto à análise dos dados a que se propõe este artigo, é desenvolvida uma descrição estrutural e uma análise do conteúdo programático de cada um dos livros didáticos, destacando-se suas particularidades em termos de divisão dos assuntos, temas abordados e exercícios propostos. Em seguida, é realizada uma análise comparativa das obras, com base em Geraldi (1984), Soares (2002) e Oliveira (2011).

\section{O contexto sócio-histórico e a educação formal do Brasil na década de 1940}

Como o propósito deste trabalho se prende a uma análise de três livros didáticos da década de 1940, uma apreciação sobre a história, os aspectos político-sociais e o conhecimento de como se efetivava a educação formal na época constituem aspectos relevantes para o entendimento da prática de ensino da Língua Portuguesa, no período de 1937 a 1945. Steinberg (1997, p.37), justificando a importância desses contextos, assim se manifesta:

\footnotetext{
${ }^{3}$ Após definir o objeto de pesquisa, as autoras procuraram livros de redação e/ou composição nos sebos de Florianópolis, onde residem, e no portal Estante Virtual (www.estantevirtual.com.br) que reúne centenas de sebos e livreiros em 21 estados brasileiros. Pode-se dizer que as autoras fizeram um recorte do possível, utilizando, para análise, os livros a que tiveram acesso.
}

Work. pap. linguíst., 13(2): 01-36, Florianópolis, jul.set,2012 
O que sei é que questões sobre as línguas não podem ser respondidas tão facilmente quanto outras questões históricas e que nenhuma resposta pode ser adequada sem uma dimensão econômica, social e política.

Para entender o contexto sócio-histórico do Brasil na década de 1940, o retorno aos anos de 1930 importa significativamente, uma vez que o movimento revolucionário, naquele período, pôs fim à República Velha ou República dos coronéis. A política do café com leite chega ao fim, a partir do momento em que Getúlio Vargas, um ano após ter sido derrotado como candidato à presidência da República, assume o poder, em regime de Governo Provisório, no Palácio do Catete, sede do Governo Federal: é o início da Era Vargas, que compreende o período de 1930 a 1937. Depois de liderar uma revolução que depôs Washington Luís, Getúlio Vargas, em 1930, assumiu a presidência do país, onde permaneceu até 1945.

\subsection{A educação formal e o ensino entre 1930 e 1937}

A Assembleia Nacional Constituinte foi instalada no Rio Janeiro, em novembro de 1931. Ao promulgar a nova Constituição, no dia 16 de julho de 1934, elege Getúlio Vargas presidente da República para o período de 1934 a 1938. A respeito dessa Constituição, Cunha (1981, p.27) assim se manifesta:

De um modo geral, a Constituição concilia interesses diversos. De um lado, atende os liberais constitucionalistas, quando estabelece eleições livres, voto secreto, o voto feminino e cria o Tribunal Eleitoral. De outra parte, agrada também aos tenentes, que embora enfraquecidos ainda detêm parte do poder, quando estabelece um certo dirigismo estatal na economia, quando cria a justiça do trabalho, a previdência social e estabelece as bases para o surgimento do salário mínimo. (apud PALMA FILHO, 2005, s.p.).

Em 1937, com o apoio militar, o então Presidente Getúlio Vargas fechou o Congresso Nacional e iniciou o Estado Novo, outorgando uma outra Constituição que Ihe dava condições para controlar os poderes Legislativo e Judiciário. Getúlio Vargas exerceu a Presidência da República até 1945, quando foi afastado por um golpe militar. Justamente nesse último mandato, Vargas ficou conhecido como "pai dos pobres", por conta de reformas sociais, da criação do salário mínimo e da Justiça do Trabalho (PALMA FILHO, 2005).

Os historiadores costumam dividir o período em que Vargas esteve à frente do Governo Federal em duas fases: 1930-1937, que corresponde ao que se convencionou chamar $2^{a}$ República; e 1937-1945, conhecida como $3^{a}$ República. As principais repercussões para a educação brasileira advindas do movimento revolucionário que iniciou a $2^{\mathrm{a}}$ República ou a Era Vargas, em 1930, foram: a criação do Ministério da Educação e Saúde Pública, a Reforma do Ensino Secundário e do Ensino Superior em 1931, o Manifesto dos Pioneiros da Educação Nova em 1932, a Constituição Federal de 1934 e os Projetos de reforma educacional da sociedade civil, conforme Palma Filho (2005).

Work. pap. linguíst., 13(2): 01-36, Florianópolis, jul.set,2012 
Ao baixar o decreto 19.851, em 11 de abril de 1931, o ministro da educação Francisco Campos traçou os novos rumos para os ensinos secundário e superior. A finalidade de Campos está expressa na exposição de motivos que acompanhou o decreto da reforma:

[...] acrescente-se, ainda, que a finalidade do ensino secundário é de fato mais ampla do que a que se costuma atribuir-Ihe. Via de regra, o ensino secundário tem sido considerado entre nós como um simples instrumento de preparação dos candidatos ao ensino superior, desprezando-se, assim, a sua função eminentemente educativa que consiste, precisamente, no desenvolvimento das faculdades de apreciação, de juízo, critério, essenciais a todos os ramos da atividade humana, e, particularmente, no treino da inteligência em colocar os problemas nos seus termos exatos e procurar as suas soluções adequadas (CAMPOS, 1931, apud PALMA FILHO, 2005, s.p.).

Por meio dos Decretos no 19.890, de 18 de abril de 1931, e $n^{\circ} 21.241$, de 4 de abril de 1932, a reforma do Ensino Secundário, empreendida pelo ministro Francisco Campos, dividiu o curso secundário em dois ciclos de estudos. Para ingressar no ensino superior, passou a ser obrigatório o primeiro ciclo, denominado ciclo Fundamental. Esse primeiro ciclo correspondia ao ensino ginasial e tinha duração de cinco anos. O segundo ciclo, Complementar, com duração de dois anos, era subdividido em três seções: para os candidatos ao curso Jurídico; para os candidatos aos cursos de Medicina, Farmácia e Odontologia; e para os candidatos aos cursos de Engenharia, Arquitetura e Química Industrial (RAZZINI, 2000).

Como o conteúdo curricular continuava a serviço de uma elite intelectual que se pretendia formar, Palma Filho (2005, s.p), a respeito da reforma Francisco Campos, ressalta que "a organização, na prática contrariava o que fora dito na exposição de motivos, anteriormente transcrita, pois continuava percebendo 0 ensino secundário como preparatório para o curso superior".

Embora elitista e de cunho conservador, no dizer de Romanelli (1999. p. 135, apud PALMA FILHO, 2005, s.p.), a reforma criou uma situação bem diferente da que existia com relação ao ensino secundário. Pela Reforma Francisco Campos se deu a organicidade do ensino secundário e estabeleceu-se também o currículo seriado, a frequência obrigatória e os dois ciclos: um fundamental, de cinco anos; e, um outro, complementar, de dois anos, além da exigência de habilitação nesses ciclos, para o ingresso no ensino superior. O currículo do curso secundário passou a servir de base para o exame vestibular. A reforma criou, ainda, a inspeção federal e equiparou todos os estabelecimentos de ensino secundários oficiais ao Colégio Pedro II, dando a mesma oportunidade aos colégios secundários particulares, desde que se sujeitassem à inspeção federal recém-criada. Para isso criou a carreira de inspetor de ensino, estabeleceu normas para o exercício das atividades docentes e seu registro junto ao Ministério da Educação.

A exigência de habilitação no ensino secundário para o ingresso nos cursos superiores, considerada a principal medida da Reforma Francisco Campos, além de ter respaldado a estabilidade do Curso Fundamental e de suas

Work. pap. linguíst., 13(2): 01-36, Florianópolis, jul.set,2012 
disciplinas, facilitou a implementação do currículo seriado e da frequência obrigatória. (RAZZINI, 2002).

Marin, Monteiro, Giovanni e Guarnieri (1998) atribuem às mudanças sociais decorrentes da industrialização e urbanização no país a ampliação de vagas nas escolas primárias e públicas. Esta ampliação se deu em função das novas exigências educacionais caracterizadas como uma fase de transição entre o desinteresse pela educação e a exigência por um treinamento mínimo de mão de obra de acordo com as necessidades do mercado de trabalho. Para atender a esta demanda social, Vargas inicia um processo de democratização de acesso ao ensino no Brasil, que ganhou substância, de acordo com Beisiegel (1997), a partir do número crescente de matrícula nos vários níveis de ensino e da criação de um modelo único de escola.

Horikawa e Jardilino (2011) esclarecem que é característica de governos populistas promover uma interseção entre escola e trabalho, ao mesmo tempo em que incitam os trabalhadores a se organizarem em partidos e sindicatos. "Nessas condições, está instaurada a luta de classes, com as novas camadas emergentes vendo na escola o meio de ascensão, lutando por uma escola existente, mas não disponível para todos" (HORIKAWA; JARDILINO, 2011,p.85).

Como a indicação de Francisco Campos para o ministério da Educação teve o apoio de lideranças prestigiosas do catolicismo, representadas pelo intelectual Alceu Amoroso Lima, a reforma de ensino, ocorrida na Era Vargas não trouxe nenhuma contribuição para o ensino primário e popular, uma vez que os setores da religião católica não se interessavam pela construção de um sistema nacional de educação pública. Assim sendo, as exigências educacionais oriundas do processo de industrialização, que Vargas pretendia alavancar, ao adotar o modelo econômico do nacional-desenvolvimento, não são efetivadas por Francisco Campos (PALMA FILHO, 2005).

As disputas ideológicas políticas, econômicas e educacionais também caracterizam os anos de 1930, tanto no Brasil quanto em outros países. A consolidação do fascismo, na Itália; do stalinismo na União das Repúblicas Socialistas Soviéticas (URSS), e a ascensão do nazismo na Alemanha influenciaram as ideias no campo político e nas esferas educacionais no Brasil. No país, segundo Palma Filho ( 2005), na área da política, havia uma rivalidade entre a Aliança Nacional Libertadora, liderada pelo comunista Luiz Carlos Prestes; e a Ação Integralista Brasileira, liderada por Plínio Salgado, que tinha um forte apoio da Igreja Católica. No campo educacional, essa divisão política dá origem à formação de dois grupos: um constituído de intelectuais liberais, socialistas e comunistas, defensores do movimento Escola Nova; e outro, formado por católicos e conservadores de diferentes matizes ideológicos, defensores de um projeto conservador de renovação educacional.

A obrigatoriedade de ensino elementar gratuito para todo o currículo escolar laico e a coeducação dos sexos, ou seja, a adoção do mesmo currículo para meninos e meninas, na mesma classe, eram os pontos de divergência entre os dois grupos mencionados. Como esses grupos não chegaram a um acordo para as diretrizes do processo educacional, por ocasião da Conferência Nacional realizada em dezembro de 1931, 26 participantes decidiram que Fernando de Azevedo escreveria o Manifesto dos Pioneiros da Educação Nova, considerado como uma proposta de criação de um sistema nacional de educação, além de apresentar um diagnóstico do processo educacional brasileiro.

Work. pap. linguíst., 13(2): 01-36, Florianópolis, jul.set,2012 
Com a Promulgação da Constituição da República dos Estados Unidos do Brasil, em 1934, foi adotada boa parte do ideário político educacional presente no Manifesto dos Pioneiros da Educação Nova, dentre eles, alguns de fundamental importância para que o país mostrasse não ter descaso quanto às questões educacionais, como: ser de competência privativa da União a elaboração de diretrizes e bases para a educação nacional; ser a educação direito de todos, devendo ser ministrada pela família e pelo poder público, afirmando ainda ser a finalidade da educação a solidariedade humana. Contempla também que o ensino primário (7 a 12 anos) deveria ser integral, gratuito e de frequência obrigatória, extensivo aos adultos. O ensino deveria tender progressivamente à obrigatoriedade até aos 18 anos e à gratuidade em todos os graus (PALMA FILHO, 2005).

Também, com a Constituição de 1934, é criado o Conselho Nacional de Educação, cuja atribuição era elaborar o Plano Nacional de Educação, que deveria ser aprovado pelo poder Legislativo. Os cargos de professores passam a ser preenchidos mediante concurso público de títulos e provas.

\subsection{A educação formal e o ensino na $3^{a}$ República ou Estado Novo (1937- 1945)}

Com o propósito de que o ensino secundário proporcionasse cultura geral e humanística; alimentasse uma ideologia política definida em termos de patriotismo e nacionalismo de caráter fascista; oferecesse condições para ingresso no curso superior e possibilitasse a formação de lideranças, uma série de reformas de ensino, conhecidas como Leis Orgânicas, quase todas realizadas sob o Estado Novo (1937-1945) de Getúlio Vargas, caracterizou a década de 1940.

Em 1942, foi promulgada a Lei Orgânica do Ensino Secundário por meio do Decreto-Lei 4.244 , de 9 de abril, de 1942, assinado pelo ministro Gustavo Capanema. A reforma, então iniciada no processo educacional brasileiro, denominada de Reforma Capanema, seguiu o mesmo processo da reforma anterior, dividindo o curso secundário em dois ciclos: o $1^{\circ}$ ciclo, intitulado "curso ginasial", era composto de quatro séries; e o $2^{\circ}$ ciclo, subdividido em "curso clássico" e "curso científico", estendia-se por três séries. A exigência da conclusão dos dois ciclos para a entrada em qualquer curso superior dava estabilidade ao curso secundário e às disciplinas do $2^{\circ}$ ciclo, cujos programas serviriam de base para o vestibular ou "exame de habilitação" (RAZZINI, 2000). Segundo Palma Filho (2005,s.p.), "em termos de conteúdo, clássico e científico, são muito parecidos. Há, apenas, uma diferença de ênfase: no científico dá-se mais atenção às Ciências Naturais e no Clássico, às Humanidades"

\section{3 A disciplina Língua Portuguesa, o livro didático e o ensino da produção escrita nos anos 1940}

A partir de uma retomada histórica do processo de ensino, desde a época colonial, é possível compreender o longo período que a disciplina Língua Portuguesa levou para ser considerada Língua Nacional e para ser incluída como disciplina curricular. Segundo Soares (2000), até os anos 1940 do século XX, 
manteve-se a tradição de ensinar a tríade retórica, poética e gramática. Soares, a esse respeito, confere:

Desde, pois, a reforma pombalina, e até fins do século XIX, estudos relativos à língua se fizeram nestes dois conteúdos, que hoje denominaríamos "disciplinas curriculares": gramática e retórica. $\mathrm{Na}$ verdade, de uma forma mais genérica, esses dois conteúdos prevaleceram do século $\mathrm{XVI}$ ao século $\mathrm{XIX}$, na área de estudos da língua (SOARES, 2000, p. 167).

O processo educacional do Brasil, na década de 1930 e 1940, continuou voltado para a classe elitista. A história do ensino secundário vem confirmar que motivos políticos e interesses econômicos, sociais e culturais marcaram a trajetória do ensino de língua portuguesa desde sua introdução nas escolas até a sua configuração como uma disciplina curricular. Para explicar por que a disciplina Língua Portuguesa se manteve até os anos 40 do século XX com a tradição da gramática, da retórica e da poética, Soares (2002) explica que se deve aos "filhos-família", denominação dada por Houaiss (1985, apud SOARES, 2000, grifo do autor) aos grupos sociais de alto nível econômico, únicos a ter acesso à escola. Para esses alunos elitizados, o conteúdo que lhes era oferecido correspondia às exigências culturais que seriam cobradas a quem pertencia a uma classe mais favorecida.

Por ter como princípio impor a soberania nacional, a Lei Orgânica de 1942 contribuiu para que a língua portuguesa fosse tratada como elemento de organização e conservação da cultura nacional, determinando, por isso, que seu estudo fosse obrigatório para todos os alunos. Como passa a figurar de forma definitiva nos programas curriculares, a Portaria Ministerial de 11 de junho de 1942 é anexada a essa Lei Orgânica, com o programa de ensino de língua portuguesa, que trazia minúcias sobre os aspectos relativos ao ensino da gramática, leitura, exercício, livros, finalidades e objetivos para cada série (O PROGRAMA DO ENSINO SECUNDÁRIO, 1942 apud BARRETO, 2005).

Segundo Razzini (2000, p.104) "o objetivo patriótico e nacionalista do ensino, presentes nas entrelinhas da reforma Francisco Campos, foi enfatizado na Lei de 1942, privilegiando o estudo da língua, da História e da Geografia nacionais". O direcionamento para pôr em execução o programa de Língua Portuguesa, segundo a Portaria Ministerial $n^{\circ} 172$, de 15 de julho de 1942, segue uma instrução metodológica que proporcione ao estudante a aquisição efetiva da Língua Portuguesa, para que esse tenha condições de expressar-se de maneira correta; para que desperte o hábito da leitura dos bons escritores, concedendoIhe os conhecimentos necessários à formação de seu espírito. Deveria também ser apresentado à origem romântica da Língua Nacional, a fim de que tivesse condições de compreender a integração do Brasil com outros países (RAZZINI, 2000).

Ainda de acordo com Razzini (2000), a reforma Capanema, como ficou conhecida a Lei Orgânica de 1942, não só ampliou a carga horária de Português de 16 para 23 horas semanais, como estendeu o curso para todo o ensino secundário. Além do aumento de aulas do vernáculo, o patriotismo ditou também os temas preferenciais dos textos de leitura no curso ginasial. Bornatto (2011)

Work. pap. linguíst., 13(2): 01-36, Florianópolis, jul.set,2012 
indica que Vargas, principalmente durante o Estado Novo, identificou que a educação do povo era o principal problema a ser enfrentado, e isso deveria ser mais abrangente que a aprendizagem do alfabeto. $O$ ensino, particularmente 0 secundário, tinha como objetivo despertar o sentimento patriótico, estimulando a oposição aos indiferentes e aos inimigos da pátria. Com poucas modificações e ajustes, a reforma Capanema marcaria o ensino secundário até o início dos anos de 1960.

Para atender a esses objetivos, o programa de português do curso ginasial, pela portaria 170, de 11 de julho de 1942, conservou a preeminência da leitura sobre as outras atividades (gramática, exercícios, redação). Nas três séries iniciais, a leitura patriótica e nacionalista substituiu a leitura literária, de prosadores e poetas contemporâneos e modernos. Os assuntos principais deveriam estar voltados para a família, a escola e a terra natal; a paisagem e a vida em cada uma das regiões naturais do Brasil; e o amor ao Brasil e a conquista da terra, o melhoramento dela e a atualidade brasileira (RAZZINI, 2000).

Mesmo com a determinação de que a leitura fosse a atividade principal, houve, no programa de Português do Curso Ginasial, um crescimento acentuado da gramática expositiva (ou normativa). Foram numerosas as gramáticas produzidas para uso escolar nesse período, a exemplo das obras de Antenor Nascentes, de Francisco da Silveira Bueno e de Napoleão Mendes de Almeida.

\section{O Livro Didático no ensino de Língua Portuguesa na década de 1940}

Em 1938, por meio do Decreto 1.006, de 30 de dezembro, os livros didáticos passaram a ser centralizados e controlados pelo Ministério da Educação e Saúde, que estabelecia as condições de produção, importação e utilização desse tipo de material (RAZZINI, 2000). Esse decreto criou, também, a Comissão Nacional do Livro Didático, com a responsabilidade de examinar, julgar e autorizar a utilização desse material tanto no ensino primário como no secundário. Entretanto, conforme Razzini (2000), professores de ensino secundário e diretores de ensino primário tinham liberdade de escolha do livro didático a ser utilizado, desde que seu uso fosse autorizado pelo Ministério da Educação.

As ações desenvolvidas pelo governo Vargas com relação ao livro didático remetem à função ideológica desse tipo de material. Choppin (2004), por exemplo, entende que, nesse contexto, o livro didático tem como objetivo difundir a língua, a cultura e os valores das classes dirigentes. Ou, nas palavras de Horikawa e Jardilino,

De uma maneira ou de outra, os livros didáticos servem como instrumentos de reconstrução de identidades, porque apresentam uma certa imagem da sociedade a que se propõem formar. $E$ ao fazê-lo, inexoravelmente, assumem posicionamentos, que colocam em confronto o que decidem expor claramente e o que decidem silenciar. (HORIKAWA; JARDILINO, 2011, p. 157).

A criação ideológica tem relação estreita com os problemas da filosofia da linguagem e, de acordo com Bakhtin (2009, 33), "cada campo de criatividade ideológica tem seu próprio modo de orientação para a realidade, mas também

Work. pap. linguíst., 13(2): 01-36, Florianópolis, jul.set,2012 
refrata a realidade à sua própria maneira". Isso é o que acontecia com o livro didático. Ao controlar a produção e distribuição desse material, o Governo Vargas refratava uma realidade que o favorecia. Compreender as rupturas entre a realidade e as imagens refratadas nos livros didáticos, portanto, podem dar indicações sobre as concepções políticas e os fenômenos ideológicos de determinada época.

Conclui-se que a imagem da sociedade apresentada pelos livros didáticos corresponde a uma reconstrução que obedece a motivações diversas, segundo época e local, e possui como característica comum apresentar a sociedade mais do modo como aqueles que, em seu sentido amplo, conceberam o livro didático gostariam de que ela fosse, do que como ela realmente é. (CHOPPIN, 2004, p. 557).

Além da função ideológica, Choppin (2004) atribui três outras funções para o livro didático: referencial, já que constitui o suporte dos conteúdos educativos; instrumental, uma vez que põe em prática métodos de aprendizagem; documental, por oferecer conteúdos textuais e/ou icônicos que tem o objetivo de desenvolver o espírito crítico do aluno. Essas funções, de acordo com o autor, são assumidas conjuntamente ou não, e podem variar dependendo do ambiente sociocultural, da época, dos níveis e dos métodos de ensino.

\subsection{Concepção de língua e de ensino da escrita na década de 1940}

No processo de ensino e de aprendizagem na década de 1940, a língua era concebida como um conjunto de estruturas gramaticais, sem quase nenhuma preocupação com os usos que falantes-ouvintes e escritores-leitores fazia dessas estruturas. Havia uma concepção conservadora que entendia a língua como um sistema homogêneo. Para Faraco (2010), esse modelo hegemônico, o modelo lógico-gramatical, expulsou do palco os atores e construiu uma língua sem falantes, uma vez que se manipularam incontáveis dados linguísticos, em especial em suas dimensões morfológica e fonético-fonológica.

A língua estava a serviço da representação do pensamento, uma vez que o foco da leitura e da produção escrita se centralizava no autor do texto, obedecendo às intenções por ele especificadas. As práticas de leitura e de produção escrita se voltavam para o autor e as intenções direcionadas para serem efetivadas em sala de aula.

\subsection{Onsino da produção escrita nos anos 1940}

Em termos do processo ensino e aprendizagem, houve mudanças nos procedimentos didáticos em relação à retórica e à poética, em especial à expressão escrita, na disciplina Português, nesse período:

Continuou-se a estudar a gramática da língua portuguesa, e continuouse a analisar textos de autores consagrados, ou seja: persistiu, na verdade, a disciplina gramática, para a aprendizagem sobre o sistema da língua, e persistiram a retórica e a poética, estas sim, sob nova roupagem: à medida que a oratória foi perdendo seu lugar de destaque tanto no contexto eclesiástico quanto no contexto social, a retórica e a poética foram assumindo o caráter de estudos estilísticos, tal como hoje

Work. pap. linguíst., 13(2): 01-36, Florianópolis, jul.set,2012 
os conhecemos, e foram-se afastando dos preceitos sobre o falar bem, que já não era uma exigência social, para substituí-los por preceitos sobre o escrever bem, já então exigência social. (SOARES, 2002, p.165).

Razzini (2000) comenta como a fusão dessas três disciplinas numa só, que passou a se denominar Língua portuguesa, no final do Império, ocorreu de forma paulatina, abordando ainda como se efetivou a inclusão da redação e da composição nas escolas.

Inicialmente as aulas de português no Colégio Pedro II, restritas ao primeiro ano do curso secundário, dedicavam-se apenas ao estudo da gramática. Aos poucos, foram absorvendo [...] conteúdos das aulas de retórica. Primeiro vieram a leitura e a literatura (1855), para auxiliar o ensino da língua [...]. Depois da ascensão do português nos exames preparatórios (reponsável pela ampliação da carga horária) entraram no currículo de português a redação e a composição (1870) (RAZZINI, 2000, p. 238-239).

Rojo (2008, p.80-81), a respeito de como ocorreu a implantação da cultura brasileira na escola secundária, inclusive a cultura da redação e da composição, constata a relevância dos seguintes fatos:

Em primeiro lugar, o estudo da gramática [...] sempre antecedeu, nos anos escolares, o uso da língua, seja na poética, seja na retórica. Em segundo lugar, a poética (os gêneros literários) sempre teve peso majoritário nos exercícios de uso da língua que se davam no ensino. Como bem mostra Razzini, primeiro vieram a leitura literária e a recitação (1855), para auxiliar o ensino da língua. A redação e a composição em outros gêneros ( retóricos, deliberativos ou demonstrativos-dissertação e argumentação) vieram vinte anos depois. (grifos da autora).

Abgar Renault, Diretor Geral do Departamento Nacional de Educação, expediu a Portaria 190, de 24 de abril de 1939, para instruir inspetores, diretores e professores do ensino secundário sobre o ensino da língua e da história nacional. As aulas de português deveriam ter dois terços de exercícios orais e de redação e que, a essa última, caberia $60 \%$ da nota das provas (RAZZINI, 2000).

\section{Concepção de sujeito, de professor e de aluno na década de 1940}

Se as condições históricas fazem ser o que somos, nessa hipótese, seríamos sujeitos instituídos; se premidos pelas condições históricas, mas não por elas determinados, nos fazemos o que somos; nesta hipótese, somo seres constituídos (GERALDI, 2010). Sobre a constituição subjetiva do sujeito, Torezam (2009) faz as seguintes considerações:

está intimamente relacionado com a concepção de que o campo do sujeito é efeito, em especial, da linguagem e de uma trama de relações pré-existentes ao nascimento, constituindo o que será o mito fundador

Work. pap. linguíst., 13(2): 01-36, Florianópolis, jul.set,2012 
de uma história singular. O sujeito [...] é aquele que se constitui na relação com o Outro através da linguagem (TOREZAM, 2009, p.41).

A concepção de sujeito, na década de 1940, está voltada para uma visão homogênea, com um viés unidirecional e monológico. Prevalece a noção de uniformidade do sujeito, um sujeito que não se constitui, mas que é instituído; que não é socialmente situado, tampouco historicamente datado, predominando a ideia de ser o sujeito universal e uniforme. Para Geraldi (2010), essa é uma concepção universalista de que todos os sujeitos nascem iguais - como se as condições históricas não fossem relevantes. Contrapondo-se a essa concepção, Geraldi ( 2010) aponta que o sujeito não está pronto ao nascer; é capaz de aprender e é capaz de usar os instrumentos do passado para construir o futuro (dependendo do ponto de vista, esse futuro há que ser a reprodução do status quo do passado).

De acordo com Koch (2009), a concepção de língua corresponde à concepção de sujeito psicológico, individual, dono de suas vontades e de suas ações. Sua tarefa é captar as ideias do autor, sem levar em conta as suas próprias experiências e os seus conhecimentos. É visto como EGO que constrói uma representação mental e deseja que seja captada pelo interlocutor exatamente da maneira como foi concebida. "Trata-se de um sujeito cartesiano, sujeito de consciência, dono de sua vontade e de suas palavras" ( $\mathrm{KOCH}, 2009$, p.14)

A concepção que se tem de professor dos anos 1940 pode ser equiparada à concepção mencionada por Mendes (2008): é o professor que se caracteriza pela valorização do conhecimento teórico, ainda que esse conhecimento permaneça estanque e descontextualizado. Basta saber as teorias e as tendências da época para ser professor. Esse professor não dialoga com as práticas efetivas que os indivíduos realizam em seus ambientes de atuação e vivência. É o professor que concebe a língua como um conjunto de estruturas gramaticais, com uma prática pedagógica tradicional de mostrar as classificações e nomenclaturas para cujo conhecimento trabalha excessivamente com exercícios gramaticais. Não havia um processo de interação professor aluno. Geraldi afirma:

\footnotetext{
Para manter-nos entre uma concepção de linguagem com interação e uma concepção de educação, esta nos conduz a uma mudança de atitude - enquanto professores - ante o aluno: dele precisamos para nos tornar interlocutores que, respeitando a palavra do parceiro, agimos como reais parceiros: concordando, acrescentando, questionando, perguntando, etc. (GERALDI, 1984, p. 22).
}

Embora não se possa dizer que os livros analisados neste artigo possuam uma concepção de linguagem como interação e, consequentemente, veja o sujeito como constituído socialmente a partir do outro, é possível identificar algumas atividades que vão além dos exercícios gramaticais. A partir da análise dos livros didáticos da década de 1940, desenvolvida a seguir, permite uma melhor compreensão da concepção de sujeito, de professor e de aluno nesse período. 


\section{Análise de três livros didáticos da década de 1940}

Como este trabalho tem o propósito de pesquisar a prática da escrita apresentada em três livros didáticos da década de 1940, a análise a ser realizada tem por objetivo identificar que concepção de língua, de escrita, de sujeito, de professor e de aluno direcionaram os autores dos três livros selecionados quanto à prática da escrita no processo de ensino e de aprendizagem que envolve professor e aluno. Embora tenham sido escritos na mesma década, os três livros selecionados apresentam diferenças metodológicas significativas, não só quanto à divisão dos assuntos, mas também quanto à proposta pedagógica.

\subsection{Livro Método de redação com vocabulário e gramática, de Carlos Góis}

Góis (1945) esclarece que o livro se constitui em um material de apoio para evitar que o professor corrija prova por prova. Destinado a exames de promoção de Português para os três primeiros anos do ensino ginasial, o livro de Carlos Góis é composto por modelo de cartas, descrições, narrativas, fábulas e uma historieta. $\mathrm{O}$ autor não esclarece que critério utilizou para selecionar os textos que compuseram o livro.

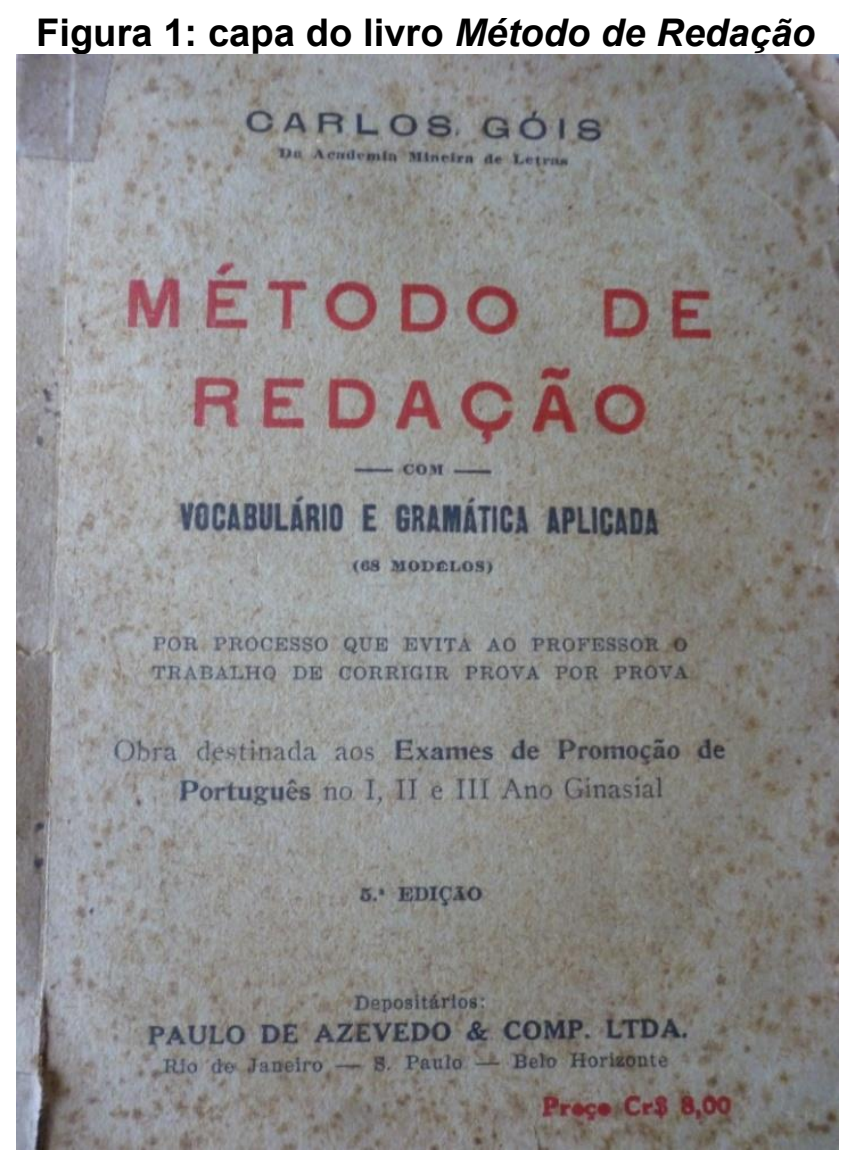

Ao orientar a prática da produção escrita, o autor, além de não enquadrar todas as tipologias textuais como composições, não menciona também a

Work. pap. linguíst., 13(2): 01-36, Florianópolis, jul.set,2012 
diferença entre redação e composição. Algumas narrativas, a exemplo de $O$ Cinema Falado e Um Prado de Corridas, o autor denomina como composição. Descrições como Uma Floresta e O Parque de Belo Horizonte não são mencionadas como composições, ao mesmo tempo em que alguns títulos aparecem como Descrição de um Passeio; Descrição de um Desastre; $e$ Descrição de uma Enchente, como pode ser visto nas figuras 2 e 3.

\section{Figura 2: Índice do livro Método de Redação - parte I}

\section{N D I C E}

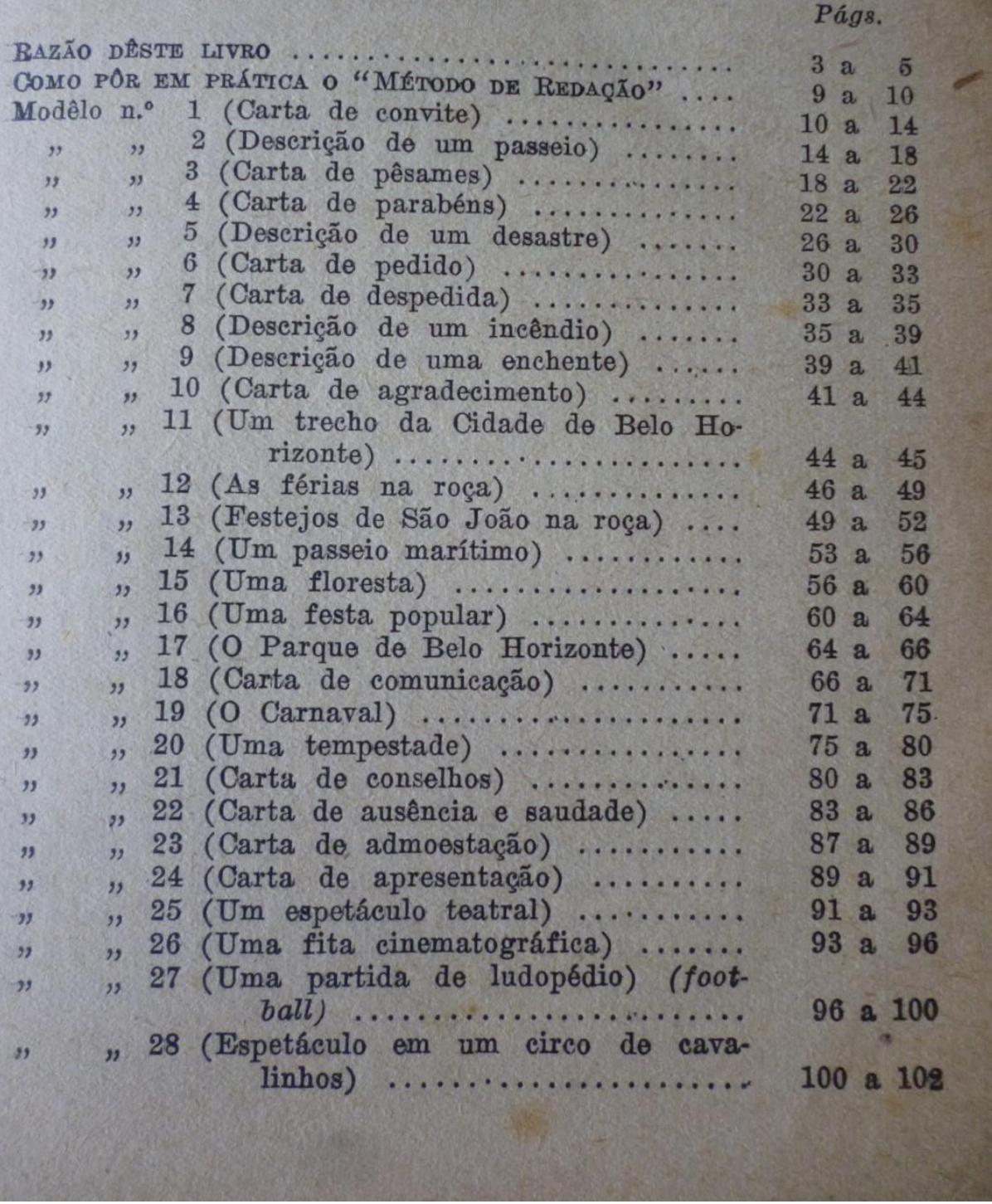

Work. pap. linguíst., 13(2): 01-36, Florianópolis, jul.set,2012 
Figura 3: Índice do livro Método de Redação - parte II

CARLOS GoIs

Págs.

Modêlo n. 29 (Um passeio em trem de ferro) ... 102 a 105 30 (Ascensão de um aeroplano) ......... 105 a 108

" 31 (Carta de consulta) ............. 108. a 111

, 32 (Outra carta de consulta) ........ 111 a 115

33 (Outra carta de consulta) ........ 115 a 117

34 (Visita a uma mina de ouro) ..... 117 a 121

35 (O cinema falado) ............... 121 a 123

36 (Um Prado de corridas) .......... 124 a 126

37 (Um concêrto no Teatro Municipal) 126 a 128

38 (O Mereado) ................... 129 a 131

39 (A Cidade de Petrópolis) ........ 131 a 134

40 (A Cidade de Ouro Prêto) ....... 134 a 136

41 (O Domingo em Belo Horizonte) ... 136 a 138

42 (A Vidz no Campo) ........... 138 a 141

43 (As Aves) ..................... 141 a 143

44 (Descrição de um teatro) ........ 143 a 144

45 (Dia de Finados) .............................. 144 a 146

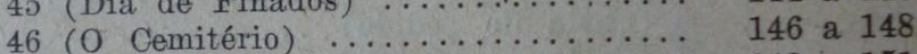

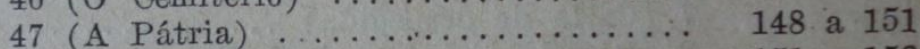

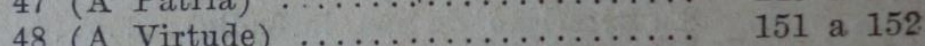

49 (A Eseola) ....................... 153 a 154

50 (A Família) .............. 155 a 157

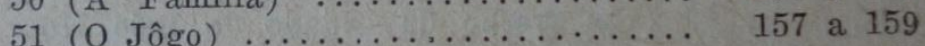

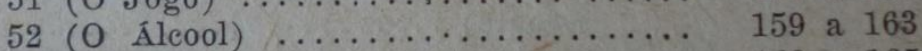

53 (As Flores) . . . . . . . . . . . 163 a 165

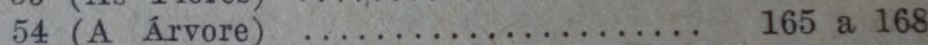

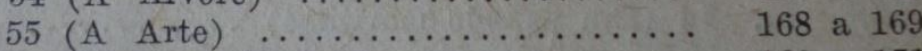

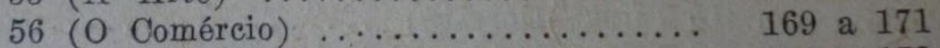

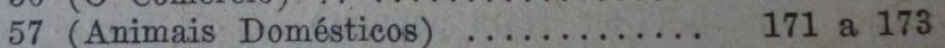

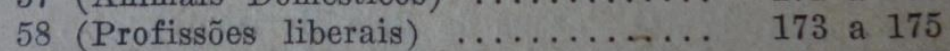

59 (A Indústria) ................. 175 a 177

60 (As Pedras Preciosas) ............ 177 a 179

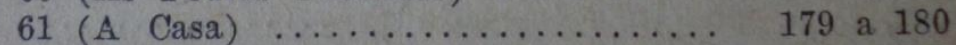

62 (Os Metais) ..................... 180 a 182

63 (A União faz a Fôrȩa - Apólogo) 182 a 185

64 (Inteligência de um Burro - Histor.) 185 a 187

65 (A Árvore e o Riacho - Apólogo) 188 a 190

66 (O Chacal e o Lagarto - Apólogo) 190 a 195

67 (O Leão e o Mosquito - Fábula)

68 (Os dois Amigos e o Urso - Fábula)

195 a 198

198 a 200

Ao final de cada texto-modelo, que vem numerado, são propostos dois exercícios, no caso das cartas, e um exercício para os outros modelos. As cartas são redigidas com variações das pessoas do discurso, para que sejam transpostas para outras pessoas; devem ser flexionadas, por consequência, as respectivas formas verbais. O segundo exercício consiste na substituição das palavras pelas sinônimas contidas no Vocabulário. O objetivo é, por meio da

Work. pap. linguíst., 13(2): 01-36, Florianópolis, jul.set,2012 
reprodução, "gravar na memória, por forma suave e indelével, o teôr da prova" (GÓIS, 1945, p. 10). A partir disso, pode-se depreender que o método de redação proposto no livro pretende ensinar a escrita por meio da cópia dos modelos propostos: ao reproduzir os textos, presumia-se que o aluno desenvolveria habilidades suficientes para escrever sobre assuntos diversos, quando precisasse.

Talvez por isso não haja, nos exercícios propostos pelo livro, estímulo à interação entre alunos e professores, o que é reforçado pelo subtítulo do texto: "por processo que evita ao professor o trabalho de corrigir prova por prova". Se o professor, por meio desse livro, não era incentivado a corrigir provas, o processo de refacção e de efetivo aprendizado da escrita ficava comprometido. $\mathrm{Na}$ apresentação da obra, a que o autor denominou "Razões dêste livro", são expostas as vantagens de ensino de redação por meio dos modelos apresentados: a desvalorização do professor, o tempo livre excessivo gasto em correções de textos e o fato de que o ensino de redação sempre constituiu "um dos problemas mais sérios de quanto se antolham ao Professor de Português no árduo ministério de sua ingratíssima profissão" (GÓIS, 1945, p.3).

Apesar de os 68 modelos apresentados serem precedidos pela seção Vocabulário e Gramática Aplicada (figura 4), não há indicação do que deveria ser feito com as normas gramaticais apresentadas, já que os dois exercícios propostos não abordam a questão gramatical. A Gramática Aplicada é, na verdade, prescritiva, já que se podem perceber, nos trechos abaixo, normas do bem falar e do bem escrever:

"Que se realizará; no que te digo. - a variação pronominal átona se acha-se antes do verbo por atração do pronome relativo que" (p.11).

"Privando-o - o pronome pessoal oblíquo o acha-se depois do verbo (enclítico), porque êste se acha no gerúndio (não regido da preposição em)" (p.21)

"Já se fazem preces - Preces são feitas (o se é uma partícula apassivante); o verbo acha-se no plural em concordância com o sujeito 'preces'” (p.41).

Figura 4: Seção Vocabulário e Gramática Aplicada 


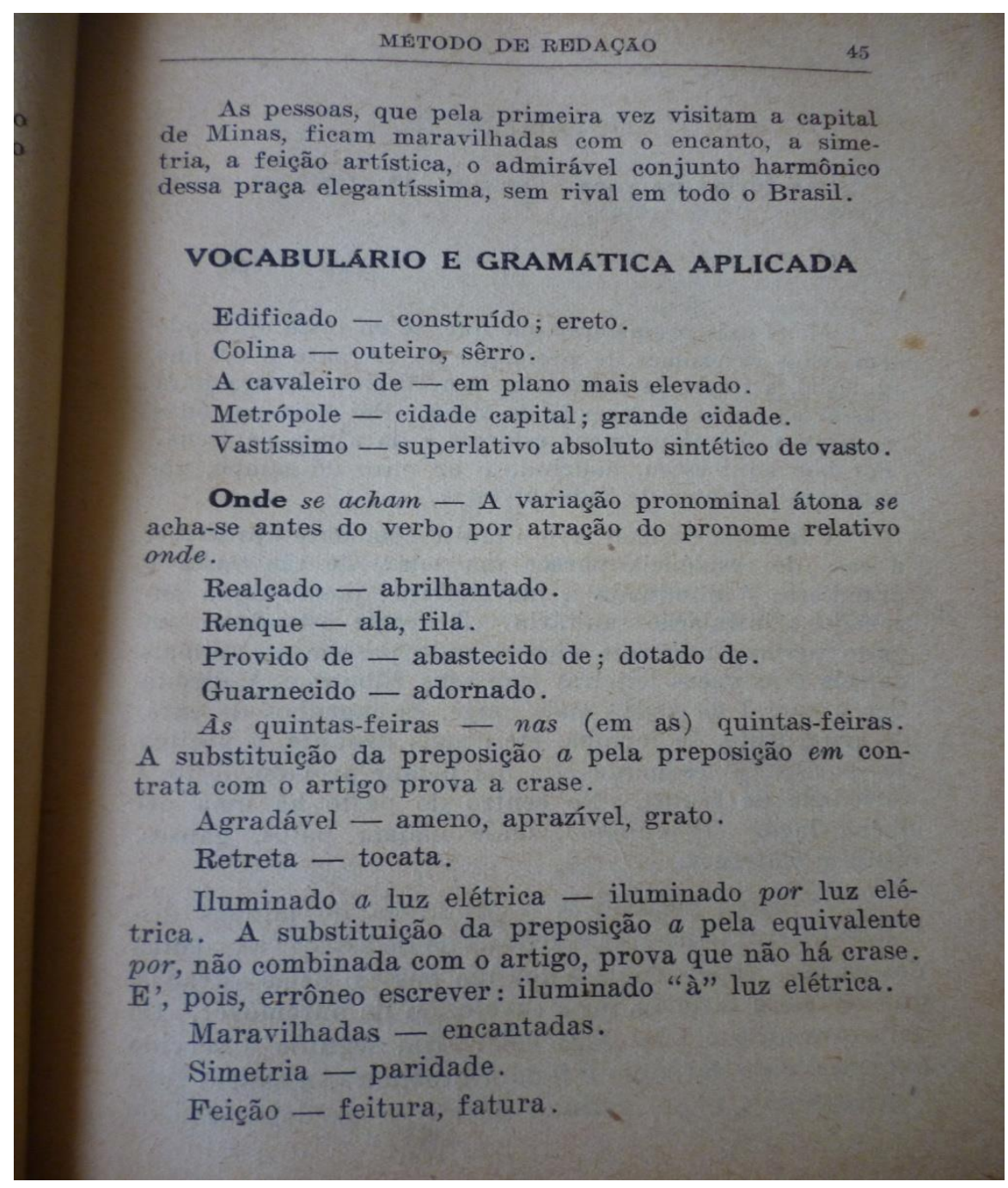

Com relação aos textos que o autor apresenta para leitura, a maioria segue as leis orgânicas que orientavam o Programa de Português das três primeiras séries, conforme a Portaria Ministerial n. 172, de 15 de julho de 1942, que explicitava a forma de instrução metodológica para execução do Programa de Português, o que incluía a formação do espírito do aluno e o respeito à pátria, à família e à escola, conforme os trechos abaixo:

1. "Não sou muito apreciador do carnaval por causa de minhas crenças religiosas. E você? Talvez seja da mesma opinião que eu: é pena que o dinheiro gasto com tantas futilidades não seja aplicado a melhor fim, isto é, a custear os orfanatos, os asilos da velhice, as santas casas de misericórdia. Se é esta a sua opinião, seremos dois a pensar do mesmo modo" (GÓIS, 1945, p.72).

2. "Estima e venera teus professores, acata as suas advertências, segue à risca os seus conselhos. Sê amigo de teus condiscípulos; trata-os com lealdade e urbanidade; nunca os denuncieis, salvo em inquérito disciplinar, quando fôres intimado a dizer a verdade. Evita, porém, as más companhias; escolhe com cuidado os que forem dignos de tua amizade. Sê assíduo às lições, não te distraias em aula, não deixes de comparecer às provas escritas: em resumo, cumpre à risca o teu dever". (GÓIS, 1945, p.80).

Work. pap. linguíst., 13(2): 01-36, Florianópolis, jul.set,2012 
3. "É preciso afastar-se, como me afastei, do convívio familial para sentir o quanto é dura e áspera a luta pela vida, para avaliar a indiferença dos estranhos, para verificar a falta que fazem os parentes" (GÓIS, 1945, p. 85).

4. "Pátria é o país onde nascemos, nos criamos e educamos, cujo solo pisamos, cuja língua falamos, cujo ar respiramos, cujas belezas naturais admiramos, cuja História veneramos, cujos heróis cultuamos, cujas tradições zelamos e conservamos, cuja integridade estremecemos e defenderemos com o sacrifício da própria vida"( GÓIS, 1945, p. 93 ).

5. "Escola é a casa do ensino. É o recinto sagrado, onde o professor prepara o espírito e o caráter da criança, talhando-a para ser um homem digno, um cidadão capaz" (GÓIS, 1945, p.153).

6. "A escola é um prolongamento da família, porque os mestres continuam na escola a educação, que os pais, em casa, incutem nos filhos. Por isso devem os alunos respeitar os mestres como 'segundos pais"'. (GÓIS, 1945, p.153).

7. "A escola é uma miniatura da sociedade, porque na escola todos vivem em comum, porque nela se formam relações dos alunos para com os mestres (relações de inferior a superior), relações dos alunos entre si (relações de igual a igual). As relações estabelecem deveres e obrigações. Na prática dos deveres e obrigações esboça-se a luta pela vida, a concorrência social". (GÓIS, 1945, p.153).

8. "A segunda origem da família é o casamento. Sem o casamento não há família, porque a união é ilícita, não passando do que se chama 'concubinato'”. (GÓIS, 1945, p. 155).

Além de seguir as leis orgânicas da época, reafirmando valores morais e patrióticos, o livro de Góis (1945) confirma a análise de Soares (2000) sobre os livros didáticos do período, que eram baseados na tríade retórica, poética e gramática. Entretanto, a abordagem da gramática, nessa obra, é superficial, não havendo indicação de como as observações prescritivas sobre o assunto podem ser utilizadas pelo aluno.

\subsection{Livro Prática de Redação de Raul Gómez}

Figura 5: Capa do livro Prática de Redação

Work. pap. linguíst., 13(2): 01-36, Florianópolis, jul.set,2012 


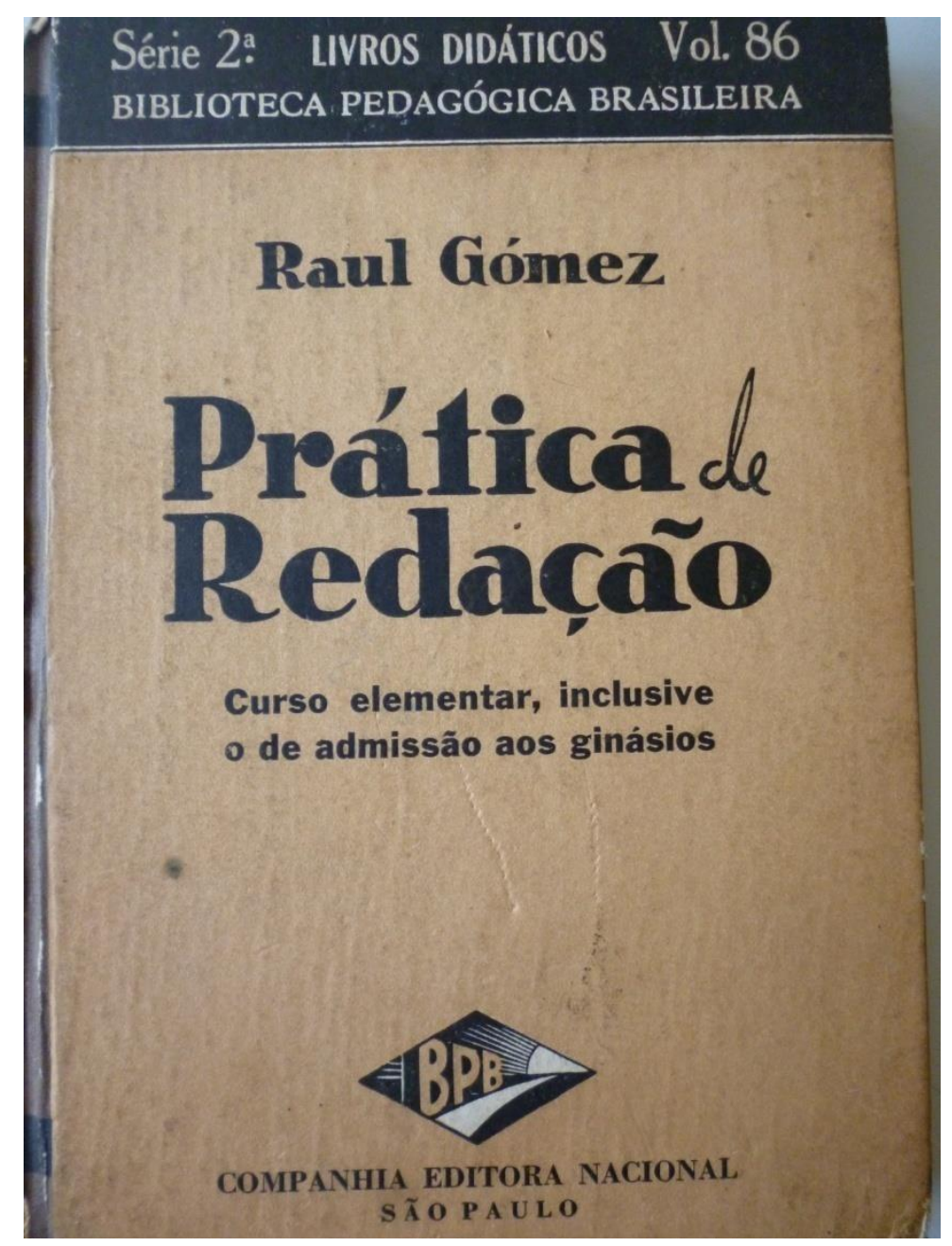

O livro didático de autoria de Raul Gómez, série $2^{\mathrm{a}}$, volume 86 , traz impressa a denominação "Livros Didáticos", realçando também o nome da Biblioteca Pedagógica Brasileira. Prática de Redação é um livro voltado para o curso elementar, inclusive para o curso de admissão ao ginásio. O livro possui 20 lições, com temas variados que, de acordo com Gómez (1944), são de interesse das crianças. Dentre esses, as estações do ano, os animais, os locais de passeio etc., como pode ser observado na figura 6 :

Figura 6: Î́ndice do livro Prática de Redação 


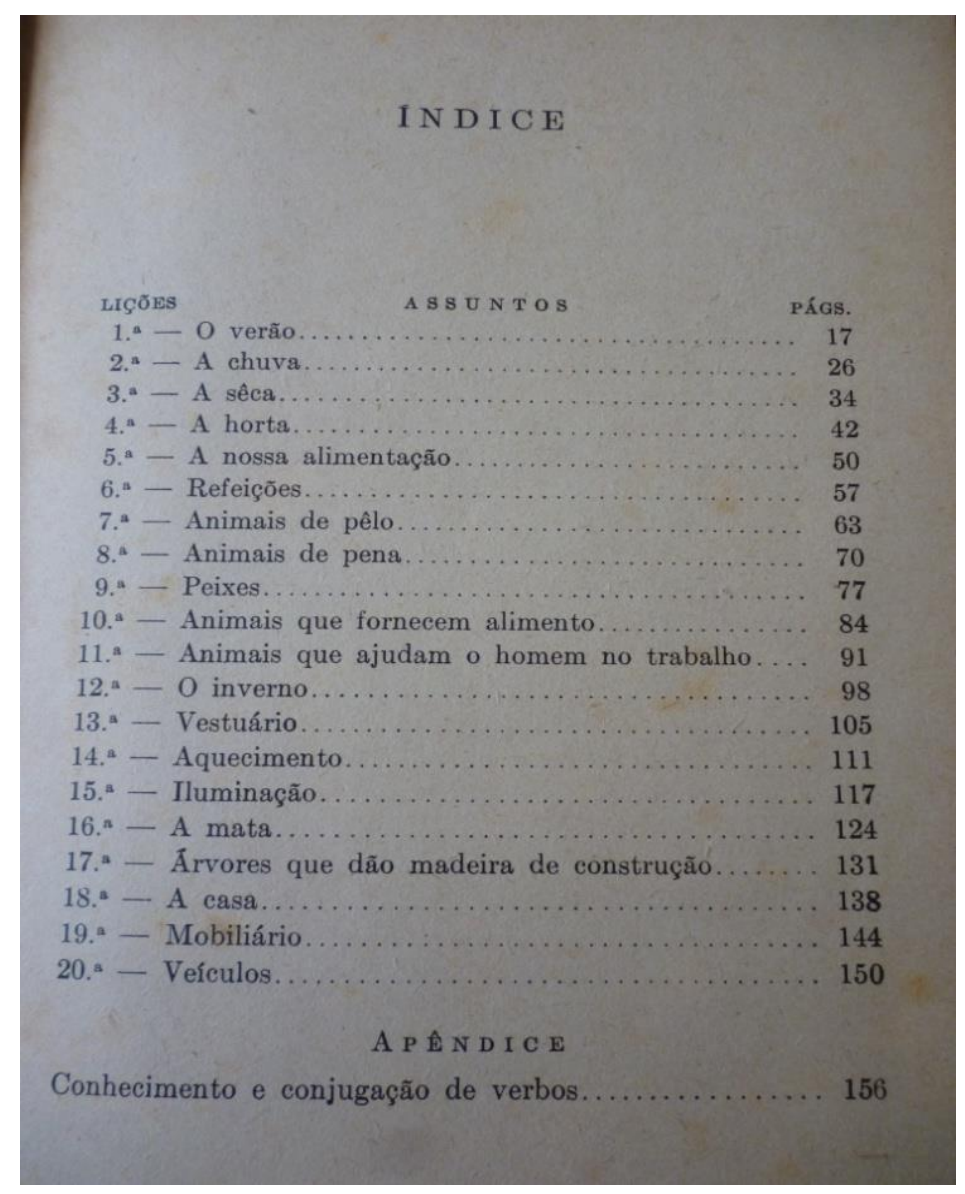

Cada lição possui 5 passos: exercícios concretos, exercícios abstratos, verbos, leitura e redação. Cada uma dessas fases, ilustradas no Quadro 1, são consideradas pelo autor importantes de serem seguidas do início ao fim. De acordo com o autor, a obra é ativa, e reduz "o trabalho do professor a um por cento e ergue o dos alunos a noventa e nove por cento" (GÓMEZ, 1944, p.13). Ao professor, durante a execução dos exercícios propostos por parte dos alunos, cabe o papel de fiscalização do cumprimento das tarefas e de orientação, devendo ele exigir "que a criança execute as ordens expressas desde a primeira à derradeira linha do volume" (GÓMEZ, 1944, p.13).

Work. pap. linguíst., 13(2): 01-36, Florianópolis, jul.set,2012 
Quadro 1: Fases do Livro

\begin{tabular}{|l|l|}
\hline Fase & Exercícios \\
\hline $\begin{array}{l}\text { Primeira: Exercícios } \\
\text { Concretos }\end{array}$ & $\begin{array}{l}\text { I - Observação } \\
\text { II- Documentação } \\
\text { III - Associação } \\
\text { IV - Expressão Concreta }\end{array}$ \\
\hline $\begin{array}{l}\text { Segunda: Exercícios } \\
\text { Abstratos }\end{array}$ & $\begin{array}{l}\text { Copiar, completando } \\
\text { Copiar, pontuando } \\
\text { Copiar, corrigindo }\end{array}$ \\
\hline Terceira: Verbos & $\begin{array}{l}\text { Dramatização de verbos } \\
\text { Exercícios para completar, copiar e } \\
\text { decorar verbos }\end{array}$ \\
\hline Quarta: Leitura & $\begin{array}{l}\text { Indicação de leitura silenciosa; busca } \\
\text { de sinônimos; cópia de trechos do } \\
\text { texto com substituição de sinônimos; } \\
\text { indicação de interpretação da leitura }\end{array}$ \\
\hline Quinta: Redação & $\begin{array}{l}\text { I- Exercício Oral } \\
\text { II - Exercício Escrito }\end{array}$ \\
\hline
\end{tabular}

Os exercícios da primeira fase tinham como objetivo enriquecer o cérebro do aluno a partir das observações realizadas (GÓMEZ, 1944), e consistiam em 4 exercícios, com 6 a 7 indicações, cada um, para que o aluno percebesse, documentasse e estabelecesse associações com relação aos fenômenos abordados em cada uma das lições, conforme quadro 2, abaixo: 
Quadro 2: Exemplos de exercícios da primeira etapa de cada lição

\begin{tabular}{|l|l|l|l|}
\cline { 2 - 4 } \multicolumn{1}{l|}{ Etapa } & O verão & A chuva & A seca \\
\hline Observação & $\begin{array}{l}\text { Registre a hora mais } \\
\text { quente do dia }\end{array}$ & $\begin{array}{l}\text { Verifique qual o mês } \\
\text { de maior e de menor } \\
\text { período de chuva }\end{array}$ & $\begin{array}{l}\text { Recorde-se e } \\
\text { marque quando } \\
\text { começou e quando } \\
\text { terminou a maior } \\
\text { sêca que você } \\
\text { presenciou }\end{array}$ \\
\hline Documentação & $\begin{array}{l}\text { termômetro ou uma } \\
\text { figura ou um } \\
\text { desenho de } \\
\text { termômetro }\end{array}$ & $\begin{array}{l}\text { Fotografias de dia } \\
\text { de chuva }\end{array}$ & $\begin{array}{l}\text { Reúna fôlhas ou } \\
\text { flores submetidas à } \\
\text { seca }\end{array}$ \\
\hline Associação & $\begin{array}{l}\text { Compare o calor da } \\
\text { sua localidade com } \\
\text { o calor de outros } \\
\text { lugares }\end{array}$ & $\begin{array}{l}\text { Recorde onde chove } \\
\text { mais ou menos do } \\
\text { que onde você está. } \\
\text { Onde nunca chove? }\end{array}$ & $\begin{array}{l}\text { Verifique se na sua } \\
\text { localidade as sêcas } \\
\text { são prolongadas e } \\
\text { periódicas. }\end{array}$ \\
\hline $\begin{array}{l}\text { Expenhe uma } \\
\text { Concreta }\end{array}$ & $\begin{array}{l}\text { Desengão } \\
\text { árvore ou uma } \\
\text { paisagem no verão, } \\
\text { o sol nascendo ou } \\
\text { aparecendo }\end{array}$ & $\begin{array}{l}\text { Desenhe a cena de } \\
\text { uma pancada } \\
\text { d'água que } \\
\text { surpreende uma } \\
\text { multidão na rua }\end{array}$ & $\begin{array}{l}\text { Desenhe uma cena } \\
\text { de seca }\end{array}$ \\
\hline
\end{tabular}

A segunda e a terceira fases, exercícios abstratos e estudo dos verbos, (conforme Quadro 1), possuem destaque na lição, já que, segundo o autor, a partir dos exercícios propostos nessa lição é possível aprender a gramática intuitivamente, por meio da prática. Das nove páginas destinadas às cinco fases propostas em cada lição, 6 são destinadas aos exercícios abstratos e ao estudo do verbo, que estão relacionados à gramática normativa: dramatização de tempos verbais, correções de conjugações, conjugações, cópias e atividades para decorar os verbos propostos. Na fase do verbo, o aluno deve indicar o modo, tempo, número e pessoa. A importância do estudo do verbo é destacada pelo autor: "sem aquele [o verbo] ninguém fala nem escreve: Devemos sabe-lo como a taboada" (GÓMEZ, 1944, p.14). Nesse caso, pode-se observar que o importante para o aprendizado da escrita é a fixação da norma, confirmando a análise de Brito (1997), que indica que, na redação escolar, o aprendizado das regras gramaticais seria suficiente para o domínio dos discursos.

A atividade de leitura proposta pelo livro, na quarta fase de cada lição, não é comentada pelo autor que solicita ao aluno ler o texto da lição, visualizar a cena descrita no texto, verificar o sinônimo de algumas palavras, relacionar os substantivos, adjetivos e verbos. Por último, é pedido ao aluno que interprete o que o escritor disse, como pode ser visto na figura 7:

Work. pap. linguíst., 13(2): 01-36, Florianópolis, jul.set,2012 
Figura 7: Exercício de leitura do livro Prática de Redação



O quinto passo, a redação, é composto de dois exercícios ${ }^{4}$ : o primeiro, comum a todas as lições, chamado de exercício oral, solicita que o aluno narre o que "viu, anotou, coligiu e executou" no primeiro passo. Já o exercício escrito varia de acordo com o tema de cada lição, conforme os exemplos abaixo:

"Escreva, narrando o que sentiu, viu e como se defendeu num dia de calor muito intenso" (GÓMEZ, 1944, p.25).

"Escreva, contando como você e outras pessoas ficaram, agiram e se defenderam quando surpreendidas por um temporal" (GÓMEZ, 1944, p.33).

"Escreva, contando como foi a sêca em sua casa, em sua rua, ou no local ou cidade em que você vive e como se defendeu ou se defenderam contra ela" (GÓMEZ, 1944, p. 41).

Como pode ser observado nos excertos acima, os temas propostos também funcionam como uma espécie de roteiro para a escrita do aluno, confirmando a visão homogênea e monológica do sujeito, que desconsidera as

\footnotetext{
${ }^{4}$ Como mostrado no Quadro 1.
} 
suas condições históricas. Além disso, o livro de Gómez (1944) parte do princípio que saber escrever é saber pensar, o que pode ser observado a partir da análise da primeira fase da obra, na qual o aluno deve ter seu cérebro enriquecido por meio de exercícios específicos (de acordo com Quadro 2). É por isso que o livro é concebido de forma a levar o aluno a fazer observações e análises diversas a respeito do tema sugerido no exercício escrito, ao final de cada lição.

\subsection{Livro A linguagem usual e a composição, de Júlio Nogueira}

A capa do livro já indica que a obra foi premiada pela Academia Brasileira de Letras ( $A B L)$, o que pode ser atribuído ao fato de que o método sugerido pelo autor se propunha a "ensinar suavemente, sem o dogmatismo áspero das regras" (p. 5). No entanto, não há indicações, em toda obra, sobre o motivo que tenha levado à $A B L$ conferir-lhe tal premiação.

Figura 8: Capa do livro A linguagem usual e a composição

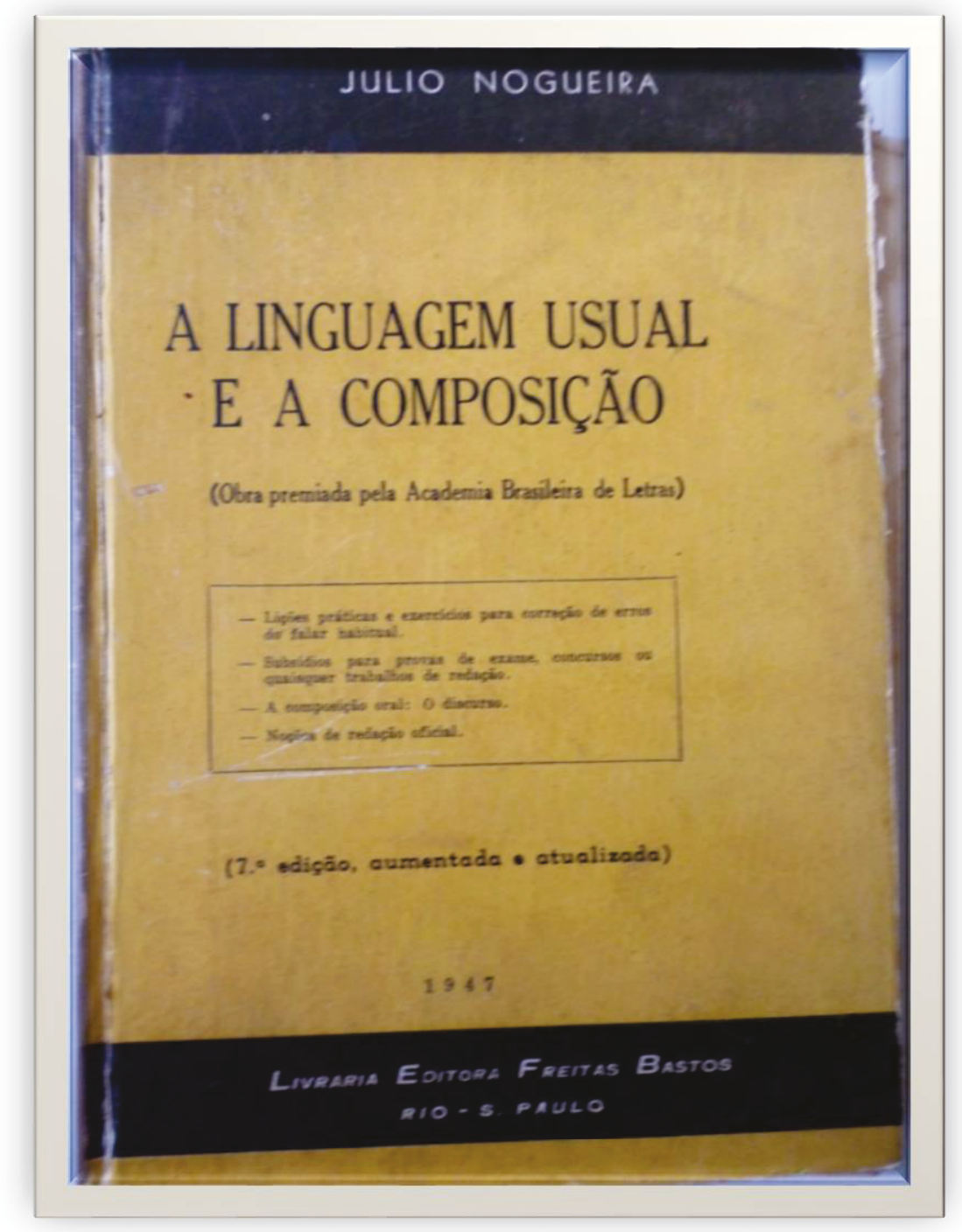

Work. pap. linguíst., 13(2): 01-36, Florianópolis, jul.set,2012 
O livro se estrutura em quatro partes: a primeira, que possui 148 páginas, é destinada a aspectos gramaticais normativos; já a segunda possui instruções e modelos de escrita, além de temas para dissertação. O autor faz diferenciações entre composição, cartas, diálogos, fábulas, paráfrases, provérbios, pensamentos e máximas.

A distinção entre redação e composição, na tradição francesa que repercute em materiais do Brasil, é uma questão de autoria: redigir é organizar por escrito, desde frases soltas a textos inteiros, a partir das ideias de outro autor; compor é organizar as próprias ideias, mesmo que segundo um modelo estabelecido. Existe uma progressão no aprendizado da redação à composição (BORNATTO, 2011, p.140).

Uma demonstração de que os autores faziam diferença entre redação e composição se encontra em Razzini, (2000, p.80), ao afirmar que "depois da ascensão do português nos exames preparatórios (reponsável pela ampliação da carga horária), entraram no currículo de português a redação e a composição (1870)".

Já a terceira parte do livro é destinada à composição oral e a quarta, à redação oficial. A seguir, serão detalhadas cada uma das seções destinadas à escrita. Como pode ser observado na figura 9, o livro é dividido em dois grandes blocos: um de gramática, que constitui a primeira parte do livro, e outro de escrita, com as outras três partes, conforme já assinalado.

Figura 9: índice do livro A linguagem usual e a composição - parte I 


\section{INDICE DA DISPOSIÇÃO DA MATÉRIA 1.a PARTE}

Algumas palavras

A estética da língua falada.

Erros de acentuação tônica

Erros de estrutura vocabular

Correções e sugestões

Distinção entre vocábulos

Significação das palavras

Coletivos especiais

Vozes de animais

Adjetivos pátrios

Peregrinismos

Pronomes sujeitos

Possessivos e pronomes em relação à forma tu

Possessivos e pronomes em relação às formas, você, o senhor, V. S. ${ }^{a}$ V. Ex. ${ }^{a}$ etc

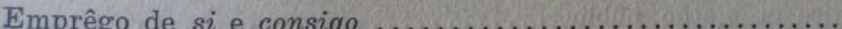

Pronomes complementos em relação com infinitivos ............

Combinaç̃es de formas pronominais átonas ..................

Combinações de formas pronominais com as formas verbais .......

Combinações com preposições

Colocação de pronomes átonos

Emprêgo do imperativo

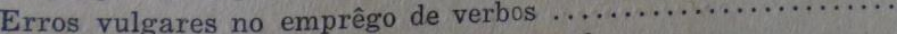

Emprêtul

Concordâncias anômalas

Grafia

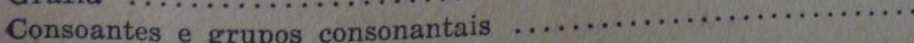

Troca e supressão de letras

Figura 10: índice do livro A linguagem usual e a composição - parte II

Work. pap. linguíst., 13(2): 01-36, Florianópolis, jul.set,2012 


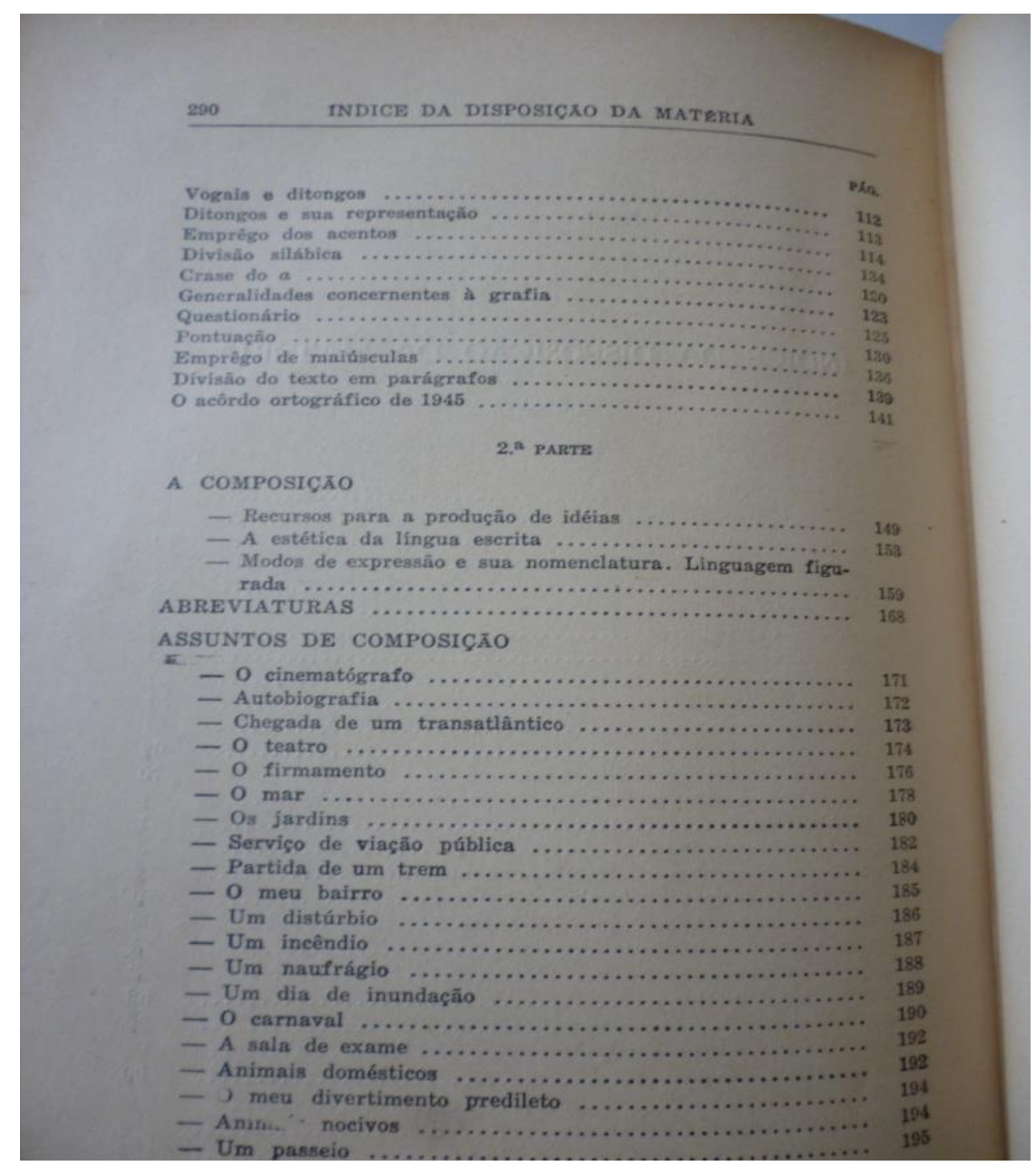

Já no início do segundo bloco, quando trata de composição, o autor traz orientações que se diferem dos outros dois livros apresentados anteriormente: neste, há indicação para que o aluno siga um método, que consiste na utilização de coeficientes protetores, que, alerta Nogueira (1947, p. 149), "não serão sempre os mesmos nem no mesmo grau para todos os assuntos, mas há-os para tudo". Entretanto, o autor não define em que consiste cada um desses coeficientes, apenas exemplifica como eles seriam utilizados no caso de uma composição sobre amizade, conforme quadro abaixo:

Work. pap. linguíst., 13(2): 01-36, Florianópolis, jul.set,2012 
Quadro 3: exemplos de utilização dos coeficientes protetores

\begin{tabular}{|l|l|}
\hline Coeficiente & Exemplo \\
\hline Definição & amizade é um sentimento que consiste em estimar a outrem \\
\hline Distinção & amizade pode ser verdadeira ou apenas aparente \\
\hline Considerações Gerais & no sentido de cada um semear amizades por toda parte \\
\hline Antecedentes & $\begin{array}{l}\text { como dizem respeito a fatos, acidentes, crimes, sinistros } \\
\text { etc., não se aplicam ao assunto }\end{array}$ \\
\hline Tempo & $\begin{array}{l}\text { pode ser considerado como cadinho para a verdadeira } \\
\text { amizade }\end{array}$ \\
\hline Lugar & a distância não é nociva à verdadeira amizade \\
\hline Comentários & já foram feitos dispersamente nesse plano \\
\hline $\begin{array}{l}\text { Narrações a propósito do } \\
\text { tema }\end{array}$ & $\begin{array}{l}\text { podemos recorrer a fatos históricos ou lendários que se } \\
\text { apliquem à matéria }\end{array}$ \\
\hline Consequências & não apresentado \\
\hline Discurso direto & não apresentado \\
\hline
\end{tabular}

De acordo com o autor, a partir da utilização desses coeficientes, evita-se que se escrevam apenas as primeiras frases com empolgação, para, em seguida, exaurirem-se as ideias. Seguindo as orientações propostas, é possível organizar as linhas gerais da composição, escrevendo-a a partir de um plano geral:

Façamos também o esbôço da nossa composição; distribuamos os assuntos que ela comporta, de maneira harmônica, para que não saia das nossas mãos uma obra contrafeita, disforme nas proporções, um monstrengo, no caso de gigantismo. (NOGUEIRA, 1947, p.151).

Ainda nessa seção sobre as orientações gerais para se elaborar uma composição, quando trata de estética da língua escrita, o autor aborda questões de certa forma inovadoras para o seu tempo, conforme os trechos abaixo:

Assim como não basta conhecer as leis da métrica para ser poeta, assim também o conhecimento das regras da linguagem não basta para que alguém seja escritor. Se dermos a um grupo de indivíduos o mesmo quadro, determinando-Ihes que façam dele uma descrição literária, veremos depois como difere o trabalho de cada um, não só quanto à extensão, como ainda quanto ao colorido das imagens, à vivacidade, às expressões, às associações de idéias e outros característicos próprios da atividade individual. É que nem todos possuem no mesmo grau a faculdade de manifestar o seu pensamento, dado que as impressões fossem idênticas, o que muito dificilmente acontece. (NOGUEIRA, 1947, p.153).

A correção e a forma são elementos distintos. Quanta beleza, quanta concepção original, quanta imagem feliz se encontra por vezes na poesia popular, no folk-lore e tudo numa linguagem incorretíssima! Por outro lado, como repugna ao nosso paladar literário a forma que certos

Work. pap. linguíst., 13(2): 01-36, Florianópolis, jul.set,2012 
escritores rigorosamente corretos mas indigestos, massudos, ásperos na exposição! (NOGUEIRA, 1947, p.154).

Essa posição pode ser considerada como inovadora visto que, de acordo com Soares (2004), o ensino de língua portuguesa, desde as suas origens ${ }^{5}$, esteve a serviço de grupos social e economicamente privilegiados, únicos a ter acesso à escola, o que continuou a acontecer na década de 1940. Assim, de acordo com a autora, na época em que o livro de Júlio Nogueira foi publicado, era comum a análise de textos de autores consagrados, e a disciplina Língua Portuguesa era voltada para ensinar gramática, ou seja, o sistema da língua.

Quando Nogueira (1947) reconhece a diversidade do trabalho de escrita dependendo do indivíduo, é possível lembrar de Bakhtin (2010 [1919-1921)], que considera que devido às condições temporais e espaciais, nenhuma pessoa pode ocupar o lugar de determinado sujeito. Ou seja, devido às experiências e relações com outros sujeitos, cada existência é singular e irrepetível. E isso vai se refletir no texto produzido por esse sujeito: "Todo texto tem um sujeito, um autor", e esse autor deve ser entendido, "antes de tudo, a partir do acontecimento da obra, como participante dela, como orientador autorizado do leitor" (BAKHTIN, 2003[1979], p. 191). Não há, de acordo com Bakhtin, um registro passivo do autor na produção de determinado texto. "O autor criador é, assim, quem dá forma ao conteúdo: ele não apenas registra passivamente [...], mas, a partir de uma certa posição axiológica, recorta-os e reorganiza-os esteticamente" (BAKHTIN, 2003[1979], p. 39).

Ao contrário do que era comum na época, Júlio Nogueira faz tais observações para destacar a importância do planejamento do texto, a fim de que se obtenha sucesso na escrita de uma composição, destacando que o conhecimento do sistema da língua não é suficiente para isso. Nogueira (1947, p.156) também chama a atenção para a necessidade de revisar o que foi escrito, inclusive lendo em voz alta, já que "o ouvido revelará cousas que passam despercebidas aos olhos mais experimentados".

Em seguida, o autor apresenta 28 assuntos de composição, e explica, em cada um dos temas, qual dever ser a linha argumentativa de cada um dos textos escritos, como pode ser observado na figura abaixo:

Figura 11: 0 que deve ser escrito de acordo com o tema proposto

\footnotetext{
${ }^{5}$ A disciplina português se originou após a fusão da retórica, da poética e da gramática, disciplinas nas quais se fazia o ensino da língua portuguesa até o fim do Império, em uma única disciplina que passou a se denominar Português. $O$ que aconteceu foi que a disciplina português manteve, de certa forma, até os anos 40 do século $\mathrm{XX}$, a tradição da gramática, da retórica e da poética.
} 


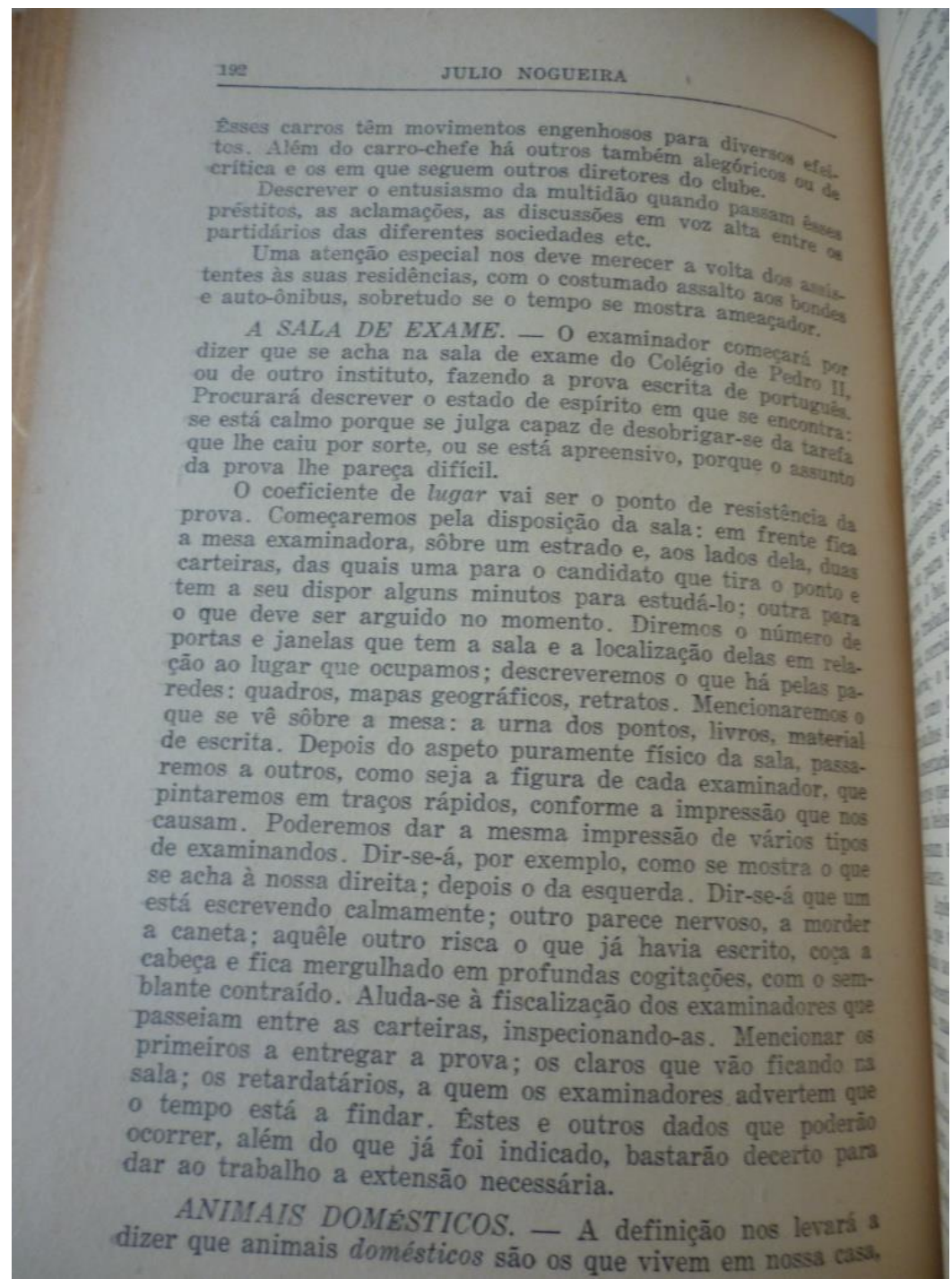

Ainda na segunda parte, o livro apresenta instruções para se escrever uma carta: inicialmente, são feitas considerações iniciais sobre o endereçamento e as primeiras mensagens de cumprimentos. Em seguida, Nogueira (1947, p.210) apresenta "em síntese, a norma que devemos adotar para cada um dêsses gêneros"6.

Na sequência, o livro apresenta instruções de como escrever diálogos em textos literários, bem como fábulas e, finalmente, paráfrases. Nesse último item Nogueira (1947) se detém um pouco mais, explicando como se pode interpretar um trecho qualquer, reescrevendo-o com palavras próprias para, então, apresentar modelos de paráfrases de poemas e poesias. Depois, são

\footnotetext{
${ }^{6}$ Ainda que não se falasse em "gêneros do discurso", essa concepção já se fazia presente nos livros didáticos para o ensino da leitura e da escrita. Alguns deles considerados importantes para a formação na época, eram contemplados no ensino da produção escrita. Era comum a escrita de cartas variadas, como: carta de parabéns por motivo de aniversário, de formatura, prêmio, nomeação; carta de pêsames; carta de encomenda; carta de apresentação, recomendação etc. "A escrita de cartas era também avaliada pela escola brasileira em meados do século XX". (BORNATTO, 2011,p. 141).
}

Work. pap. linguíst., 13(2): 01-36, Florianópolis, jul.set,2012 
apresentados alguns sonetos, fornecidos como tema para realização de paráfrases, com subsídios para que o aluno as desenvolva. Também nessa seção, Nogueira sugere que os "coeficientes amigos", apresentados anteriormente, sejam utilizados para a realização do exercício.

Figura 12: Exemplo de síntese para desenvolvimento de paráfrase

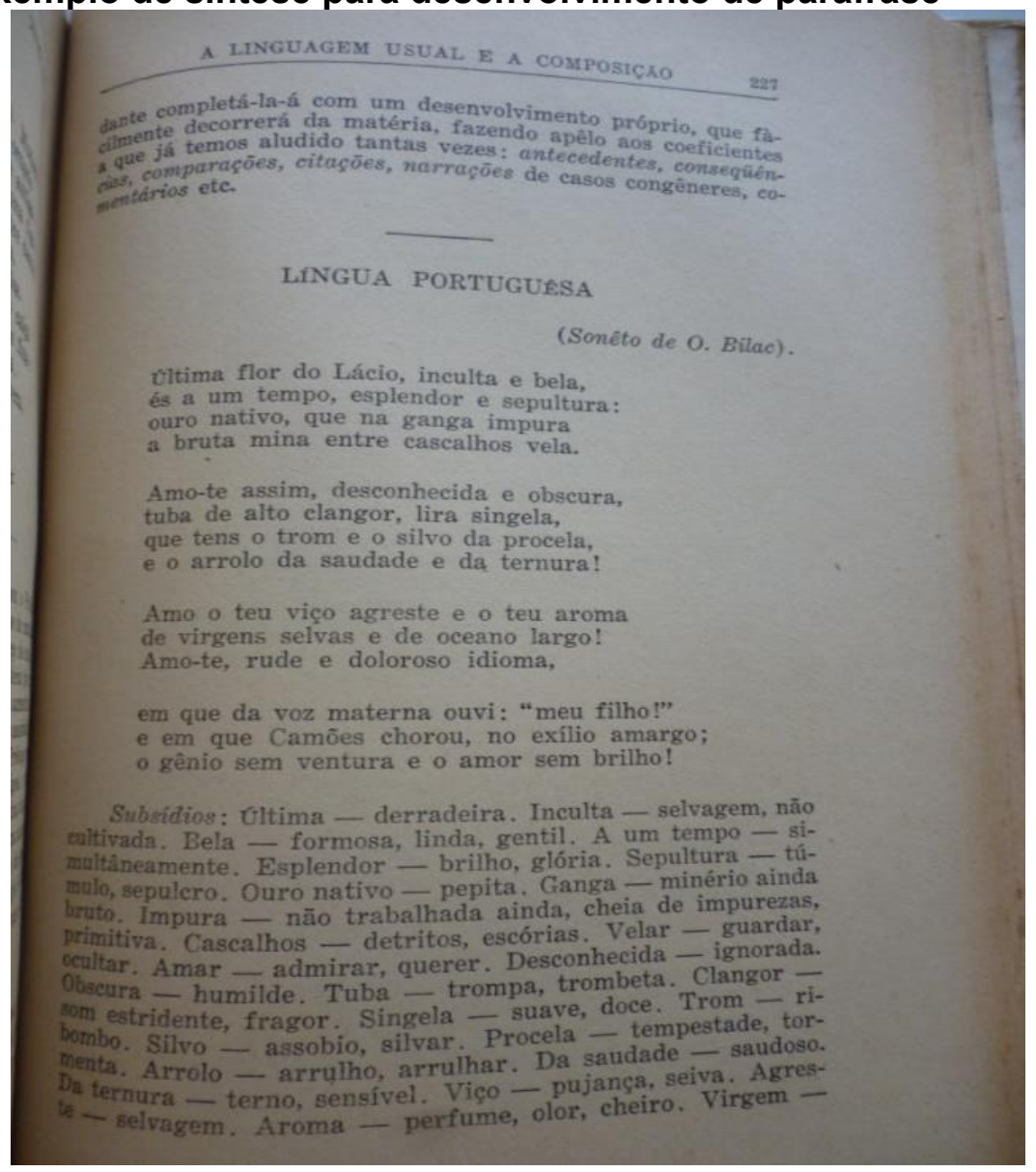

Finalmente, são apresentados temas de dissertação para alunos que já estejam "adiantados na arte de escrever" (NOGUEIRA, 1947, p.245), conforme exemplo abaixo:

O tempo que muda todas as cousas, muda também a nossa disposição de espírito'.

- Mencionar as transformações de ordem física e as de ordem moral; as nossas idéias, os nossos hábitos (brinquedos, diversões, leituras etc.). (NOGUEIRA, 1947, p. 245).

A terceira parte é dedicada à composição oral, mas, como foge ao escopo do trabalho ora apresentado, não será abordada neste momento. A última parte apresenta noções de redação oficial, que consiste, basicamente, em apresentar ao aluno modelo de decretos, circulares, mensagens presidenciais etc. Ou seja, não há instruções para a escrita desses documentos, o que se pode depreender que, no caso de documentos oficiais, para o autor da obra, seria suficiente um 
modelo para que se obtivessem as habilidades necessárias de escrita de tais registros.

Como os modelos traziam a formalidade, a disposição gráfica e as formas de tratamento, o aluno poderia, ao imitá-lo, familiarizar-se com a linguagem. Segundo Bornatto (2011), essas práticas permitem supor que o ensino da escrita no ginasial tinha como objetivo principal formar redatores que, ao conhecer os preceitos gramaticais e ortográficos necessários, teriam habilidades para escrever de forma adequada e correta. É importante observar, no livro de Nogueira (1947), como essa última parte difere do segundo bloco do livro, quando trata de composição, conforme análise anterior. Enquanto no momento em que trata de composição o autor apresenta propostas inovadoras para época, nessa última parte, em que trabalha com redação oficial, o autor segue as tendências de ensino de língua portuguesa da década de 1940.

\section{Análise dos Livros}

Soares (2002) indica que a partir das décadas de 1950 e 1960, é intensificado o processo de depreciação docente: com a popularização do acesso a escola, passa a haver um recrutamento mais amplo e menos seletivo do professor. Como consequência, a profissão passa a contar com baixos salários e com condições precárias. Por isso, o professor começou a buscar alternativas que facilitem o seu trabalho e a tarefa de preparar aulas e exercícios é transferida para o livro didático.

O início desse processo já pode ser percebido a partir da análise das obras Método de redação, Prática de redação e A linguagem usual e a composição. No primeiro livro, como já assinalado na sua descrição, há um destaque, na capa, dando conta de que o processo proposto evita ao professor inclusive a tarefa de corrigir prova por prova. O segundo livro destaca o papel do professor durante sua utilização por parte do aluno, que deve ser o de orientador e fiscalizador. Já na terceira obra, o autor enfatiza que essa não se destina apenas ao ensino das escolas, e por isso seu usuário pode contar com total autonomia com relação ao professor durante a sua utilização.

Com relação ao ensino da escrita, há que se considerar que, de acordo com Soares (2002), a disciplina de Português, até a segunda metade do século $\mathrm{XX}$, era desenvolvida como no fim do império, já que seu ensino continuava baseado na tríade retórica, poética e gramática. As atividades relacionadas à retória e à gramática podem ser observadas, principalmente, no livro Prática de Redação, embora com peso maior de exercícios gramaticais. Entretanto, nas atividades de redação propostas sempre há um exercício oral e outro escrito.

Essa obra vai ao encontro das considerações de Brito (1997), quando indica que a redação como gênero escolar (subdividida em dissertação, narração e descrição) desvincula o exercício efetivo de leitura e escrita, privilegiando-se a fixação da norma. "A concepção subjacente é a de que leitura e escritura são habilidades independentes do domínio dos discursos que portam e que o sujeito pode adquiri-las com treino e assimilação das regras" (BRITO, 1997, p.108).

Já o livro Método de redação não apresenta exercícios gramaticais, e a seção Vocabulário e Gramática Aplicada, como explicado em sua apresentação, não esclarece o que deve ser feito com as informações sobre as regras normativas constantes na obra. A terceira obra analisada, A linguagem usual e a composição, possui relativa autonomia de gramática e texto, que vêm separados

Work. pap. linguíst., 13(2): 01-36, Florianópolis, jul.set,2012 
inclusive graficamente: a gramática está na primeira metade do livro e as atividades de escrita, na segunda metade. A obra aqui analisada, embora esteja em sua sétima edição, já apresenta essa característica que, para Soares (2002) começa a aparecer a partir da década de 1950.

A concepção de linguagem dos livros analisados está relacionada à linguagem como expressão do pensamento, já que, de acordo com Geraldi (1984, p.43): "essa concepção ilumina, basicamente, os estudos tradicionais" Para conseguir se expressar, é necessário saber pensar nessa perspectiva. Dessa forma, os exercícios iniciais propostos no livro Prática de Redação se destinam a fazer com que o aluno desenvolva reflexões com relação ao tema de cada lição, por meio de observação, documentação, associação e expressão concreta. Nogueira (1947), no livro A linguagem usual e a composição, explicita isso no prefácio do livro:

Dentre as matérias em que se fazem sentir essas insuficiências do ensino ginasial [...], avulta a linguagem, a mais nobre de tôdas, a que em tôdas se revê, como condição precípua da expressão do pensamento. Cumpre que todos falem e escrevam com relativa correção, clareza, espontaneidade e até com discreta elegância. (NOGUEIRA, 1947, p.5).

Com relação à Prática de Redação, como o livro induz o aluno a fazer somente cópias com substituição de vocábulos, pode-se concluir que a língua, nessa obra, está voltada completamente para o aspecto imanente (código, sistema e estrutura) e o texto é visto como simples produto da codificação. De acordo com Koch (2009), nessa concepção de língua como estrutura, o sujeito é determinado, assujeitado pelo sistema, caracterizado por uma espécie de não consciência. Bakhtin (2008 [1963]), por outro lado, esclarece que o sujeito se constitui a partir do outro, não sendo, entretanto, moldado pelas relações sociais. O sujeito bakhtiniano tanto é influenciado por sua relação estabelecida com o outro como influencia nessa relação.

Dessa forma, do ponto de vista bakhtiniano, pode-se interpretar a obra Prática de Redação como filiada ao que Bakhtin [VOLOSHINOV] (2009 [1929]) denomina de objetivismo abstrato: a língua é vista como um código e o núcleo da realidade linguística é o sistema das formas fonéticas, gramaticais e lexicais. Pode-se considerar, no caso desse livro, que a língua é vista como um sistema imutável.

Da mesma forma que Oliveira (2011), em sua pesquisa sobre os livros didáticos de 1955 a 1973 de Theobaldo Miranda dos Santos, as obras aqui analisadas vão de encontro, de certa forma, com a literatura científica a respeito do ensino de redação nos meados do século XX. Embora tenha bases na gramática tradicional, em que escrever bem equivale a dominar as regras gramaticais normativas por meio de narração, descrição e dissertação, também puderam ser encontrados, nos três livros aqui estudados, exercícios para a escrita de cartas, principalmente. No livro $A$ linguagem usual e a composição, também aparecem fábulas, parábolas, decretos e leis, papeis internos e certidões.

Essa obra, aliás, apresenta peculiaridades com relação às duas outras analisadas: o ensino processual da escrita por meio de coeficientes protetores; a importância conferida às etapas de planejamento e revisão da escrita; o reconhecimento de que o domínio de regras gramaticais não é suficiente para que se saiba escrever; o reconhecimento de que, mesmo não estando de acordo com

Work. pap. linguíst., 13(2): 01-36, Florianópolis, jul.set,2012 
a gramática normativa, muitos escritos da cultura popular possuem valor literário e cultural.

Nogueira (1947) enfatiza que os recursos gramaticais e normativos devem ser utilizados durante o processo da escrita, embora não sejam suficientes. Em alguns exercícios propostos no livro $A$ linguagem usual e a composição, pode-se considerar que haja certa preocupação em atender a uma necessidade social, já empregando os usos da linguagem.

\section{Considerações Finais}

Buzen (2005) explica que o livro didático de língua portuguesa tem sido objeto de investigação desde a década de 1960. Entranto, segundo o autor, a maioria dessas pesquisas procura avaliar os objetos de ensino com o olhar da ciência moderna, embora não seja indicado avaliar um livro didático de outra época a partir da comparação com as concepções teóricos-metológicas atuais. O livro didático é um objeto cultural e, como tal, deve ser interpretado à luz de suas condições de produção. $O$ importante, durante o processo de pesquisa com o livro didático, é "entender como se dá o processo dinâmico em que saberes, objetos e práticas de ensino, que trazem tempos históricos e concepções de aprendizagem diferentes [...]" (BUZEN, 2005, p.569).

Foi justamente para compreender a concepção de ensino e de aprendizagem da escrita da década de 1940, que se analisaram três livros dedicados para esse fim. Como resultado, pôde-se perceber que, para as obras analisadas, a língua deveria ser expressão do pensamento: escrever bem equivalia a saber pensar. Esse resultado confirma os pressupostos teóricos em que está baseado este estudo. Outra confirmação obtida foi a importância social conferida à escrita a partir da década de 1940: Nogueira (1947), partircularmente, menciona a necessidade de se utilizar a escrita de forma apropriada na atividadade profissional; daí a importância de se aprender a redigir adequadamente.

Alguns fatos merecem investigação em outros livros didáticos, inclusive os que não sejam dedicados apenas ao ensino da escrita: o fato de os textos abordados irem além da narração, da descrição e da dissertação; a ênfase, em duas das obras estudadas, dada à escrita de cartas; e a assunção, por parte do livro didático, de elaboração de exercícios, o que, segundo Soares (2002), só viria a ocorrer a partir das décadas de 1950 e 1960. Merece também um estudo mais aprofundado os livros didáticos de Júlio Nogueira, já que a obra aqui estudada, Linguagem usual e composição (1947), apresenta diferenças significativas com relação às outras duas obras, conforme pôde ser observado no item 7 deste artigo.

Merece destaque, também, o foco dado à gramática nos três livros: enquanto o livro de Gómez (1944) destina a maior parte de cada lição aos aspectos normativos da língua, Góis (1945) passa ao largo deste assunto, abordando apenas questões pontuais. Já Nogueira (1947), divide o seu livro em dois blocos, como já mencionado: um dedicado à gramática e outro à escrita. Nessa segunda parte, o autor é enfático ao afirmar que o domínio do sistema da língua não é suficiente para que se saiba escrever. Além disso, o autor reconhece o valor e atribui importância a textos da cultura popular que não seguem os padrões da norma culta da língua.

A partir da pesquisa aqui desenvolvida, foi possível perceber que as concepções de língua e de sujeito podem indicar quais seriam os procedimentos que os professores empregavam na década de 1940 no ensino da escrita, embora

Work. pap. linguíst., 13(2): 01-36, Florianópolis, jul.set,2012 
não seja possível saber se os livros didáticos aqui analisados eram utilizados da forma como seus autores propunham ou se o professor desenvolvia outros tipos de atividades. Isso só seria possível a partir de um estudo mais aprofundado, que incluísse análise de diários de classe, depoimentos de alunos, cadernos de exercícios, avaliações, compreensão da concepção de escrita etc.

Embora este trabalho não traga respostas definitivas com relação ao ensino da escrita na década de 1940, é possível insistir na necessidade do estudo da história da língua portuguesa para, a partir do momento em que se lança um olhar ao passado, compreendam-se as condições de ensino e de aprendizagem atuais possam ser compreendidas. Se atualmente o professor de língua portuguesa não tiver noção de como a concepção de língua foi se desenvolvendo ao longo do tempo e como isso continua refletindo nas práticas de ensino atuais, ele não terá como operar mudanças significativas que possam colaborar para uma mudança nas suas atividades de ensino da língua materna. Sem essa mudança, o professor continuará prescrevendo e ditando normas que dirijam o comportamento do falante, sempre visto como um ser homogêneo, instituído e que tem uma língua completamente pronta a seu serviço.

\section{Referências}

BAKHTIN, Mikhail M. [1919-1921] Para uma filosofia do ato responsável. São Carlos: Pedro e João Editores, 2010.

Paulo: Hucitec, 2009.

[VOLOSHINOV]. [1929]. Marxismo e filosofia da linguagem. São Estética da criação verbal [1979]. São Paulo: Martins Fontes, 2003.

BARRETO, Sonia Maria Damasceno da Silva. Saberes Escolares e o ensino de português no cotidiano do curso secundário. 2005. Dissertação (Mestrado). Recife: Universidade Federal de Pernambuco, 2005.

BEISIEGEL, Celso de Rui. Educação e sociedade no Brasil após 1930. In: FAUSTO, Boris (org.). História da civilização brasileira. Tomo III, $4^{\circ}$ volume, Economia e Cultura (1930-1964). 2.ed. São Paulo: Difel, 1997. (p. 381-486).

BORNATTO, Suzete de Paula. A tradição e os singulares: o ensino de português proposto em livros didáticos por professores universitários do Paraná 1944-1980. Curitiba: UFPR, 2011.

BUNZEN, Clecio. Construção de um objeto de investigação complexo: o livro didático de língua portuguesa. Estudos Lingüísticos XXXIV, p. 557-562, 2005.

[557 / 562 ]. Disponível em: http://www.gel.org.br/estudoslinguisticos/. Acesso em: $28 / 11 / 2011$.

BRITO, Luiz Percival Leme. A sombra do caos: ensino de línguas $\mathrm{X}$ tradição gramatical. Campinas: mercado de letras, 1997. 
CHOPPIN, Allan. História dos livros e das edições didáticas: sobre o estado da arte. Educação e Pesquisa, São Paulo, v.30, n.3, p. 549-566, set./dez. 2004. Disponível em: http://www.scielo.br. Acesso em 02/08/2012.

FARACO, Carlos Alberto. Pesquisa aplicada em linguagem: alguns desafios para o novo milênio. Revista Delta, v.17, p.1-9, n. spe., 2001. Disponível em: Disponível em: http://www.scielo.br. Acesso em 12/09/2012.

GERALDI, João Wanderley. O texto na sala de aula: leitura e produção. 4.e. Paraná: Assoeste, 1984.

. A aula como acontecimento. São Carlos: Pedro e João Editores, 2010. . Portos de Passagem. 2. ed. São Paulo: Martins Fontes, 2003.

. Linguagem e ensino: exercício de militância e divulgação. Campinas, SP: Mercado de Letras, 1999.

GÓIS, Carlos. Método de redação com vocabulário e gramática aplicada, 5. ed. Rio de Janeiro, São Paulo, Belo Horizonte: Paulo de Azevedo \& COMP.LTDA, 1945.

GÓMEZ, Raul. Prática de Redação. São Paulo, Rio de Janeiro, Recife, Bahia, Porto Alegre: Companhia Editora Nacional, 1944.

HORIKAWA, Aline Yoko; JARDILINO, José Lima. A formação de professores e o livro didático: avaliação e controle dos saberes escolares. Revista Lusófona de Educação, 2010,15, 147-162. Disponível em: http://www.scielo.br. Acesso em 02/12/2010.

KOCH, Ingedore G. Villaça. Desvendando os segredos do texto. 6.ed. São Paulo: Cortez, 2006.

MALAN, Pedro Sampaio. Relações Internacionais do Brasil (1945-1964). In: FAUSTO, Boris (org.). História da civilização brasileira. Tomo III, $4^{\circ}$ volume, Economia e Cultura (1930-1964). 2.ed. São Paulo: Difel, 1997. p. 53-106.

MARIN, Dirce Chanara Monteiro; GIOVANNI, Luciana Maria; GUARNIERI, Maria Regina. Práticas docentes no ensino da leitura e linguagem no primeiro ano escolar em 1943. In: FERNANDES, Rogério; ADÃO, Áurea. Leitura e escrita em Portugal e no Brasil: 1500-1970. Actas do $1^{\circ}$ Congresso Luso-Brasileiro de História da Educação. Porto: Sociedade Portuguesa de Ciências da Educação, 1998. p.177-183.

MENDES, Edleise. Língua, cultura e formação de professores: por uma abordagem de ensino intercultural. In: MENDES, Edleise; CASTRO, Maria Lúcia 
Souza (orgs). Saberes em português: ensino e formação docente. São Paulo: Pontes Editores, 2008. p. 57-78.

NOGUEIRA, Júlio. A linguagem usual e a composição. 7. ed. Rio de Janeiro, São Paulo: Freitas Bastos, 1947.

OLIVEIRA, Alyne Renata. As atividades de redação em livros didáticos (19551973) de Theobaldo Miranda dos Santos. 2011. Dissertação (Mestrado). Florianópolis: CCE/Ufsc, 2011.

PALMA FILHO, João Cardoso. A educação brasileira no período de 1930 a 1960: a Era Vargas. In: PALMA FILHO, João Cardoso. Pedagogia cidadã. 3.ed. São Paulo: Santa Clara Editora, 2005. p.49-60.

RAZZINI, M. P. G. O Espelho da Nação: A Antologia Nacional e o ensino de Português e de Literatura (1838-1971). 2000. Tese (Doutorado). Campinas: IEL/UNICAMP, 2000.

ROJO, Roxane. Os gêneros do discurso como objeto de ensino: um retorno do trivium? In: SIGNORINI, Inês. [Re]discutir texto, gênero e discurso. São Paulo: Parábola, 2008. p.73-108.

SOARES, Magda. Português na escola - história de uma disciplina curricular. In: BAGNO, Marcos. (Org.). Linguística da norma. São Paulo: Loyola, 2002. p.155177.

STEINBERG, Jonathan. O historiador e a questione della lingua. In: BURKE, Peter; PORTER, Roy (orgs.). História social da linguagem. São Paulo: Fundação Editora da Unesp, 1997.

TOREZAN, Zeila Facci. Sublimação, ato criativo e sujeito na psicanálise. Tese (doutorado). 2009. Florianópolis: CFCH/Ufsc, 2009. 